\title{
Multi-scale geological evaluation for quarrying activities in ophiolitic rocks: implications for asbestos-related legislation
}

\author{
Gianluca Vignaroli · Girolamo Belardi • \\ Marcello Serracino
}

\begin{abstract}
This study illustrates the importance of undertaking a multi-scale geological approach when assessing ophiolites which may contain harmful asbestos. A case history from an active quarry in the Carinthia region of Austria is presented. The data obtained indicated four main zones within the heterogeneous rock mass. The study identified those horizons which could be used for commercial purposes, notably railway ballast and road subbase. Extensive testing was undertaken which confirmed that asbestiform amphiboles were not present in the quarry. Attention is drawn to the ambiguities in current legislation regarding the presence of asbestos.
\end{abstract}

Keywords Structural geology - Petro-textural analyses . Asbestos · Quarrying

Résumé Cette étude illustre la nécessité de mettre en œuvre une approche géologique multi-échelle pour évaluer le contenu en amiantes nocives dans un massif d'ophiolites. Une étude de cas provenant d'une carrière en activité dans la région de Carinthie en Autriche est présentée. Les données obtenues ont indiqué l'existence de quatre zones principales au sein du massif rocheux. L'étude a permis d'identifier les horizons qui pourraient être utilisés à des fins commerciales, notamment comme ballast de voie

G. Vignaroli $(\bowtie)$

Dipartimento di Scienze, Università degli Studi

Roma Tre, Viale Marconi 446, 00146 Rome, Italy

e-mail: gianluca.vignaroli@uniroma3.it

G. Belardi - M. Serracino

Istituto di Geologia Ambientale e Geoingegneria, Consiglio Nazionale delle Ricerche (CNR), Area della Ricerca di Roma RM1 Montelibretti, Via Salaria km. 29, Monterotondo, 300, 00016 Rome, Italy ferrée et couche de base de route. De nombreux tests ont été réalisés. Ils ont confirmé que les amphiboles asbestiformes n'existaient pas dans cette carrière. L'attention est attirée sur les ambiguités de la législation actuelle concernant la présence d'amiante.

Mots clés Géologie structurale - Analyse pétrographique et microstructurale $\cdot$ Amiante $\cdot$ Carrières

\section{Introduction}

The heterogeneous geological characteristics of a natural site are an important consideration when assessing rock excavation. A detailed definition of the lithological, structural and mineralogical/petrographical features of the rock mass is essential in order to:

1. optimize the engineering activities for selective quarrying (Räisänen and Torppa 2005);

2. control the quality of the commercial material;

3 . ensure safe conditions for workers and others affected by the quarrying (Palmer et al. 2010).

Ophiolite-bearing units are intensively mined for industrial, engineering and others uses around the world. Raw material excavated from ophiolites is of economic importance as it has a variety of uses including railway ballast and roadbed, breakwaters, and ornamental stone. Ophiolites (including basalt, gabbro, amphibolite and peridotites) occur as discrete large tectonic bodies or dispersed within flyschoid sequences as a result of the orogenic complexities (Dilek and Robinson 2003 and references therein). When quarrying activity involves ophiolites, restrictive legislation applies to reduce the health risks associated with possible asbestos exposure (Kazan-Allen 2005; Lee et al. 2008). 
Asbestos is the commercial term for some amphiboles and serpentines typically found in ophiolites. The asbestos hazard arises as microscopic fibres can become airborne when ophiolite rocks are disturbed during mining, milling and transportation (Rohl et al. 1977; Pan et al. 2005).

Although ophiolites are often described as asbestosbearing rocks, there are two major points that should be considered:

1. Not all ophiolites contain asbestos. A spectrum of geological properties promotes or restricts its occurrence including lithology, deformation, fluid contamination and tectonic/metamorphic history (Ross and Nolan 2003; Van Gosen 2007; Hendrickx 2009; Vignaroli et al. 2011). Moreover, within the same ophiolitic complex, the asbestos is not dispersed within the entire volume but may occur in concentrations at specific sites, such as deformation structures commonly replacing the original stratigraphic setting (Karkanas 1995; Andreani et al. 2005; Compagnoni and Groppo 2006; Hirauchi and Yamaguchi 2007; and Vignaroli et al. 2011 for a review);

2. Legislative criteria for asbestos-bearing rocks are mainly regional and differ from country to country. For example, in Italy Ministerial Decree No 178, 14 May 1996 provides aspects, methodologies and limits for the amount of asbestos-bearing rock material. This legislation concerns raw material that is currently excavated in Italian territory and all material that is excavated in foreign countries and imported into Italy. A paradox arises when rocks are excavated in neighbouring countries where the asbestos-related legislation adopts different criteria. For example, rock quarried in neighbouring Austria is not restricted by asbestosrelated legislation (only CE marking-EC Declaration of Conformity is considered), but must be reconsidered before being transported into Italian territory.

This paper offers some insights into the quality assessment of a heterogeneous quarry where ophiolitic rocks occur and presents a geological multidisciplinary approach carried out in an active quarrying site (Carinthia, Austria; Fig. 1), where the excavated material is used for the production of railway ballast and roadbed. The study included detailed geological mapping, a petrological and textural analysis and a quantitative chemical-morphological study of the amphiboles occurring within the rock mass. The aim was to provide scientific support for improving the quarry activities through the individuation of specific sectors in the deposit and to examine the mineralogy and petrographic properties of the excavated rock in terms of asbestos hazard. A methodological procedure to reduce the ambiguities which arise due to the current asbestos-related legislation in ophiolitic rocks is also provided.

\section{The open question}

Processing asbestos minerals during excavation of ophiolitic rocks can release isolated fibres which have a negative effect on human health, including asbestosis, mesothelioma and lung cancer (Doll 1955; Mossman et al. 1990; Hughes and Weill 1991; Gibbons 1998). The World Health Organisation considers asbestos to be a peculiar morphology of serpentine (chrysotile) and amphibole (amosite, crocidolite, anthophyllite, tremolite and actinolite) minerals characterised by individual fibres $>5 \mu \mathrm{m}$ long, $<3 \mu \mathrm{m}$ wide and with an aspect ratio (length divided by width) of $3: 1$ or greater (World Health Organization 1986; Gunter et al. 2007; Walton 1982; Churg and Wiggs 1984; Harper et al. 2008; Van Orden et al. 2008). Due to the toxicity of asbestos (it is now catalogued as Category 1 within the carcinogen minerals, IARC 1987), excavation of ophiolitic rocks is subjected to periodical quality controls consisting of the determination of minero-petrographic properties and the potential amount of asbestos within the excavated rock volume.

National laws regulate the quality control and propose criteria to classify the rock in terms of asbestos content. Italian legislation (Italian Ministerial Decree No 178, 14 May 1996) includes a list of rock lithologies potentially containing asbestos, referred to as "greenstones" (Table 1). The Decree requires a minero-petrographic characterization of the excavated rock volume and the calculation of the amount of free asbestos released from the sample during rock fragmentation. However, the term "greenstones" refers to different green-coloured rocks due to the presence of chlorite, green amphibole, epidote, and/or serpentine. In particular, the term "greenstones" (1) does not imply a rigorous definition of the petrographic/petrological characteristics of the rock, and (2) does not correspond to the geological context of the natural site where quarrying is active. As a consequence, ambiguities arise from the Italian interpretation that all "greenstones" contain asbestos.

\section{Methodologies}

A multidisciplinary study has been carried out including observations at both the meso-(field surveys) and microscale (laboratory activities), focussing on the geological properties of the excavated rock material.

The geological-structural surveys were performed in the area of active quarrying and adjacent zones, focussing on lithology, structural architecture, deformation structures (spatial distribution, persistence and kinematics) and preliminary geomechanical tests. Careful rock sampling was undertaken to discriminate different lithologies, deformation structures and related mineralization. Sampling was 


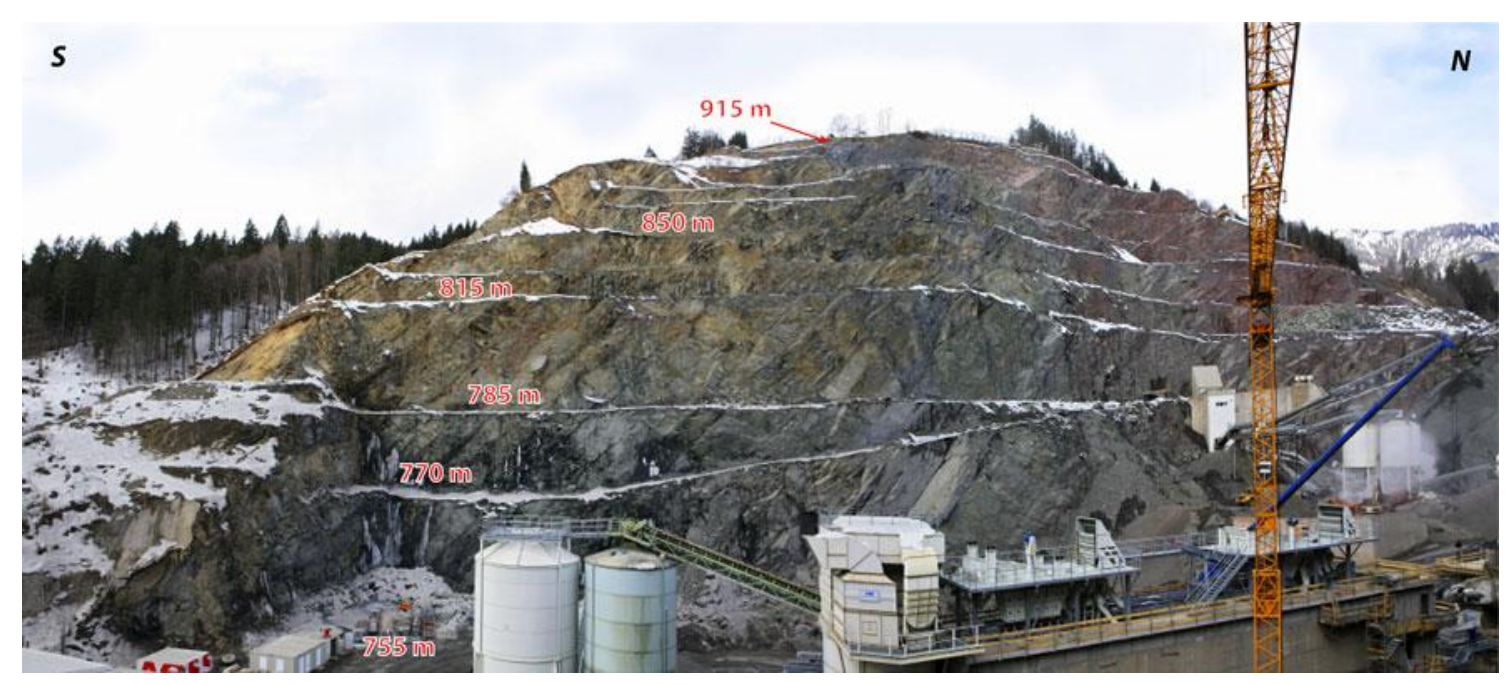

Fig. 1 Panoramic view of the quarry site where bench elevation is indicated

Table 1 Classification of the "greenstones" in terms of their asbestos content following the Italian Ministerial Decree no 178, 14 May 1996

\begin{tabular}{|c|c|}
\hline Lithotype & Main minerals \\
\hline "Serpentinites" s.1. & $\begin{array}{l}\text { Antigorite, chrysotile, olivine, ortho- } \\
\text { and clino-pyroxene, tremolite, talc, } \\
\text { dolomite, garnet, spinel }\end{array}$ \\
\hline Prasinites & $\begin{array}{l}\text { Feldspar, albite, epidote, tremolite, } \\
\frac{\text { actinolite, }}{\text { pyroxene, }}, \text { white mica }\end{array}$ \\
\hline Eclogites & $\begin{array}{l}\text { Clino-pyroxene, garnet, rutile, } \\
\text { glaucophane }\end{array}$ \\
\hline Anfibolites & $\begin{array}{l}\text { Hornblende, plagioclase, zoisite, } \\
\text { chlorite, antophyllite, ghedrite }\end{array}$ \\
\hline Actinolitic schistes & $\frac{\text { Actinolite }}{\text { olivine }}$, talc, chlorite, epidote, \\
\hline $\begin{array}{l}\text { Chloritic schistes, talc- } \\
\text { schistes, serpentine- } \\
\text { schistes }\end{array}$ & $\begin{array}{l}\text { Talc, chlorite, dolomite, tremolite, } \\
\text { actinolite, serpentine, chrysotile, } \\
\text { rutile, titanite, garnet }\end{array}$ \\
\hline Ophicalcites & $\begin{array}{l}\text { Talc, antigorite, chrysotile, tremolite, } \\
\text { dolomite, calcite, olivine }\end{array}$ \\
\hline
\end{tabular}

The underlined mineral specimen is considered as asbestos by the Decree

undertaken from all the quarry levels, based on the mesoscale properties of rock such as grain size, mineralogical assemblages and the structural anisotropy of the fabric. Nomenclature and fabric properties were identified after Tucker (2001), in particular in relation to the sorting (degree of uniformity of grain size), rounding (occurrence of grains edges due to abrasion during sedimentation) and composition maturity.

The laboratory analyses were mainly to define (1) the petro-texture and mineralogy of the rock, (2) the chemistry, and (3) the morphology of the minerals. Microscopic analyses were performed on polished thin sections $(30 \mu \mathrm{m}$ thick) prepared from selected samples cut perpendicular and parallel to the major fabric (e.g. bedding, cleavage). Initially observations were made using an optical transmitted light microscope (equipped with $2.5 \times, 4 \times, 10 \times$, $20 \times$, and $40 \times$ magnifications and digital camera acquisition) followed by a detailed study using a scanning electron (SEM) microprobe (FEI Quanta $400 \mathrm{MK} 2$ model) at $15 \mathrm{kV}$ and point-beam $1-5 \mu \mathrm{m}$ in size operating conditions.

The mineral chemistry was performed using a CAMECA SX 50 electron microprobe, equipped with five spectometers (EMPA-WDS, Electro Probe X-Ray Microanalyzer) and BSE (back-scattered electron) device for image acquisition. Analyses were performed in point-beam mode (focussed or $5 \mu \mathrm{m}$ in size) at $15 \mathrm{kV}$ and $15 \mathrm{nA}$ operating conditions. Natural and synthetic phases (wollastonite: $\mathrm{SiK} \alpha$ e $\mathrm{CaK} \alpha$, rutile: $\mathrm{TiK} \alpha$, corundum: AlK $\alpha$, magnetite: $\mathrm{FeK} \alpha$, manganese: $\mathrm{MnK} \alpha$, periclase: $\mathrm{MgK} \alpha$, orthoclase: $\mathrm{KK} \alpha$, jadeite: $\mathrm{NaK} \alpha$, F-phlogopite: $\mathrm{FK} \alpha$, and silvite: $\mathrm{ClK} \alpha$ ) were considered as standards. The mineral chemistry was compared with whole rock mineralogical characterization obtained from X-Ray diffractometry on powders from the same rock chips used for the thin sections. Powder diffraction data were collected on a fully automated Bruker AXS D8 diffractometer, operating in reflection mode, equipped with a Peltier- cooled $\mathrm{Si}(\mathrm{Li})$ solid state energy dispersive SOL-X detector in $\theta-\theta$ geometry. The measurement parameters used were: generator setting $\mathrm{Cu}: 40 \mathrm{kV} /$ $40 \mathrm{~mA}$; slits $=0.6,0.6,0.1 \mathrm{~mm}$; scan angle $(2 \theta)=0-70^{\circ}$; step width $(2 \theta)=0.04^{\circ}$; step time $(s)=4$.

\section{The geological setting of the study area}

The studied quarry is located within the district of Bleiberg-Kreuth in the Gailtal Alps of the Central Alps in 
Austria (Fig. 2a). The Gailtal Alps define an E-W trending mountain belt of the Upper Austroalpine domain consisting of continental-derived units (Palaeozoic in age) with a Palaeozoic-Mesozoic sedimentary cover. To the south, the Upper Austroalpine domain is bounded towards the Lower Austroalpine domain by the Periadriatic Element.

The geodynamics of the Central Alps was dominated by a series of tectonic processes that involved the Gondwana supercontinent (Läufer et al. 2001): (1) crustal fragmentation and production of oceanic sea floor (Upper Ordovician); (2) development of a passive continental margin (Upper Devonian); (3) activation of a subduction process along the southern continental margin, concomitantly with abundant flyschoid sedimentation in foredeep basins (Lower Carboniferous); and (4) end of oceanic subduction and subsequent continental collision (Upper Carboniferous). The Alpine tectonic produced reworking of the Variscan structures, with the development of mainly brittle, strike-slip regional fault systems (e.g. the Periadriatic Element).

Within the Gailtal Alps, the Carboniferous of Nötsch (Fig. 2b) constitutes an important tectono-stratigraphic unit consisting of a ca. 1,000 m thick sequence of silicoclastic deposits (Krainer and Vachard 2002; Hubmann et al.
2006). This sequence is bounded, both to the south and to the north, by dextral strike-slip fault systems developed during the Alpine tectonics. From top to bottom, the Carboniferous of the Nötsch groups three distinct sedimentary formations (Krainer 1992; Krainer and Vachard 2002):

1. the Nötsch Formation, a several hundred metre thick sequence composed of fossiliferous shales and siltstones with intercalated sandstones and conglomerates of turbidite origin;

2. the Badstub Formation, a ca. $400 \mathrm{~m}$ thick deposit of amphibolite breccias, conglomerates, sandstones and fossiliferous siltstones, and

3. the Erlachgraben Formation consisting of polymict conglomerates, immature sandstones (arenites and lithic wackes), siltstones and shales.

The quarrying activity is located in the Badstub Formation, a turbiditic deposit formed on a proximal continental slope along an active fault zone at a passive margin (Krainer and Mogessie 1991; Krainer and Vachard 2002; Hubmann et al. 2006). It comprises a succession of breccias and conglomeratic breccias with intercalated sandstones, siltstones and shales, interbedded by fossiliferous black shales containing abundant brachiopods, subordinate

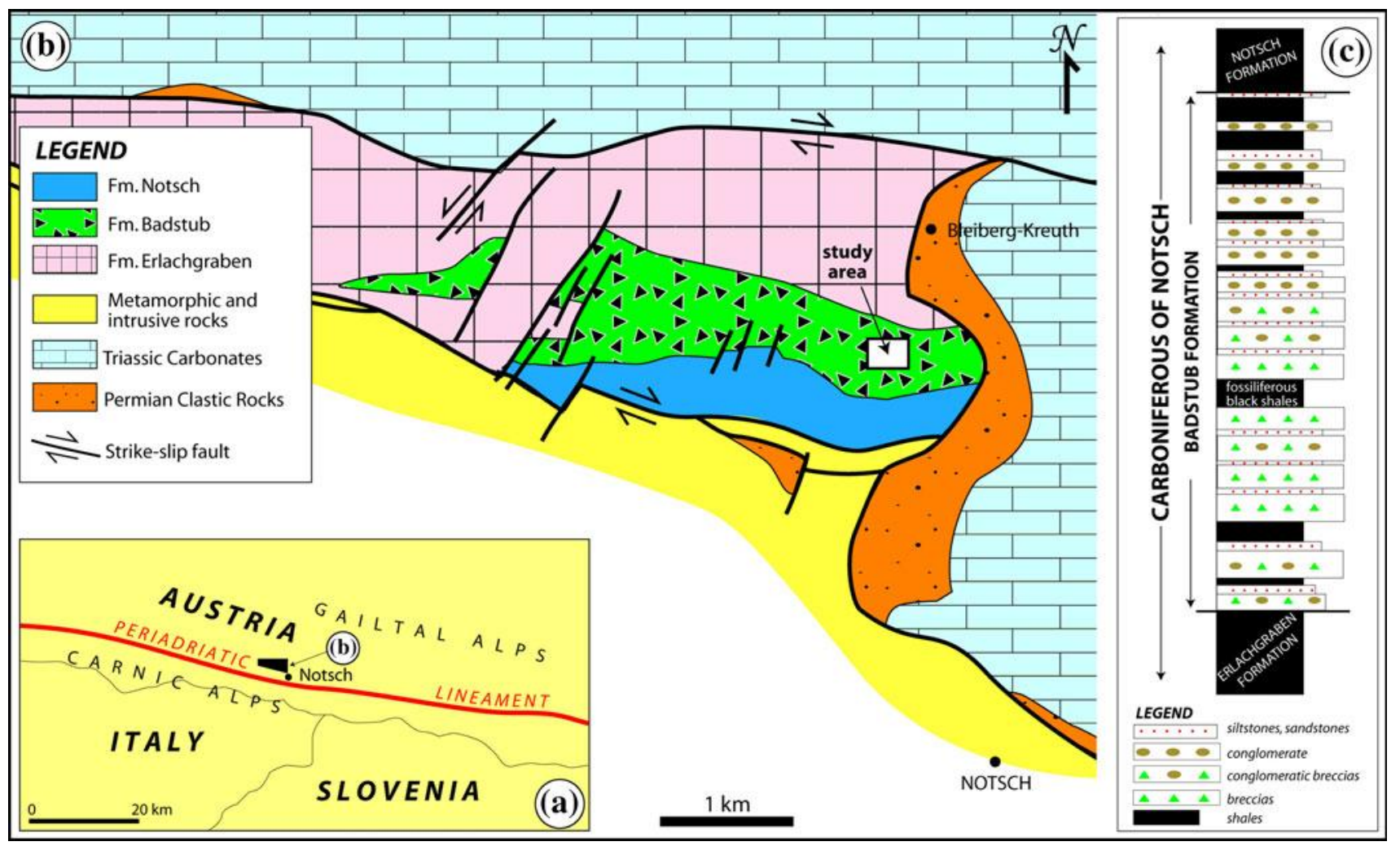

Fig. 2 a Schematic map of the Central Alps dominated by the tectonic contact between the Upper and the Lower Austroalpine domains along the Periadriatic Lineament; b geological map of the Carboniferous of Nötsch (after Krainer and Vachard 2002, modified and redrawn). Location of the studied quarry is shown; $\mathbf{c}$ simplified stratigraphic column of the Badstud Formation (after Krainer and Mogessie 1991, redrawn and modified) 
corals, and few foraminifers (Krainer 1992) (Fig. 2c). The shaley member constrains the age of the Badstub Formation at the Upper Visean (340-320 Ma). Boulders and pebbles within the breccias are dominantly amphibolitic in origin, with subordinate basalts, marbles, quartzites and granites. Amphibolitic boulders show both massive and foliated fabric defined by a green amphibole + plagioclase dominant mineral assemblage with a variable content of epidote, chlorite, quartz, ilmenite, sphene and garnet (Krainer and Mogessie 1991).

\section{Geological field data of the quarry site}

Rock exposures along the quarry benches are indicated in the geological map, Fig. 3a. Within the quarry site, the stratigraphic sequence of the Badstub Formation shows an almost regular monoclinal geometry striking $\mathrm{N} 100^{\circ}$ and dipping to the SSW with a mean dip of between $30^{\circ}$ and $50^{\circ}$ (see the stereographic projection in Fig. $3 \mathrm{~b}$ ). The thickness of bedding varies from a few centimetres to several metres and consists of both rhythmic layering (alternating parallel layers having a different colour and grain size) and graded bedding (bedding showing a decrease in grain size from the bottom of the bed to the top of the same bed). The original bedding is complicated by the occurrence of brittle deformation structures (faults and fractures) related to the Alpine tectonics. Major fault systems show both NE-SW and NW-SE strikes and are characterized by decimetric thick cataclasites that cut across the stratigraphy (Fig. 4a). The faults are dominantly strike-slip (both sinistral and dextral), but normal faults also occur (see the stereographic projection in Fig. 3b). Mineralization on the fault surfaces and within fractures is mainly recrystallized calcite (Fig. 4b). In a few cases, iron oxides have been also detected. Fractures are always related to fault deformation and follow a systematic trend throughout the rock mass (Fig. 4c).

The geological survey allowed the determination of four distinct sectors within the quarry site, based on meso-scale geological-stratigraphic properties (Figs. 3a, 4d, e) and micro-scale observations. These sectors correspond to parts of the Badstud Formation and their boundaries always match the stratigraphic layering.

- Sector I. Meters thick strata of red-coloured siltstones and sandstones are dominant, with intercalations of decimetric thick breccias and conglomeratic breccias (Fig. 5a). Stratigraphic strata boundaries have a generally tabular geometry. Within the siltstones and sandstones, clast fragments are difficult to recognise with the naked eye. Within the breccias, mafic clasts are abundant giving the green colour to the rock, but pebbles of granite and quartzite also occur (Fig. 5b). The clasts within the coarse-grained strata are dispersed within the fine-grained matrix (matrix-dominant texture). The clast/matrix ratio is variable and clastsdominant textures can be recognized, mostly in the lower part of the deposit. The dimension of the clasts varies between some few centimetres to decimetres. The degree of clast abrasion (rounding) is low, and the clast shape is generally sub-angular to sub-rounded.

- Sector II consists of stratified conglomeratic breccias with a strata thickness of $<1 \mathrm{~m}$. Pebbles of mafic composition are dispersed within a greenish matrix (Fig. 5c) but quarzitic clasts may also occur (Fig. 5d). The matrix texture is dominant within the rock volume.

- Sector III corresponds to the 5-10 m thick black shale (Fig. 5e) showing a grafitic texture characterized by lamination and the abundance of macro-fossils (trilobites, brachiopods) (Fig. 5f).

- Sector IV consists of a sequence of conglomeratic breccias and breccias varying up to several metres in thickness (Fig. 5g). Tabular contacts between stratigraphic strata are marked by the occurrence of finergrained material. A clast-dominant texture (clasts are in contact) is the most recurrent fabric property. Pebbles are mainly sub-rounded and mafic clasts often account for up to the $100 \%$ of the strata volume. Sporadic granite and quartzite pebbles occur within the matrix (Fig. 5h). Sorting is very low (5-10\%), with dimensions varying from a few centimetres to a meter.

A Schmidt hammer (GEOHAMMER model) was used to obtain a hardness index that could be correlated to provide a uniaxial strength. Tests were performed in several sites in Sectors I and IV to take into account the different geological-structural settings, such as massive structure, bedding, and fracturing systems. Table 2 summarises the results obtained by a statistical treatment of the data. In massive strata, the uniaxial strength was $>200 \mathrm{MPa}$. Bedding (i.e. the spacing between two adjacent strata bounds) influences the rock strength in Sector I, with average values slightly decreasing down to $192 \mathrm{MPa}$ (10-20 cm thick) and $143 \mathrm{MPa}(5-10 \mathrm{~cm}$ thick). A consistent reduction of the rock strength is associated with fracture spacing connected to fault systems, with minimum values of $19 \mathrm{MPa}$ obtained (1-5 cm spaced).

Although rock samples were collected within each quarry sector, special emphasis was given to Sectors I and IV which are mostly involved in excavation for ballast production. The samples used for petro-textural analyses, mineral chemistry, and observation concerning mineral morphology are listed in Table 3. 


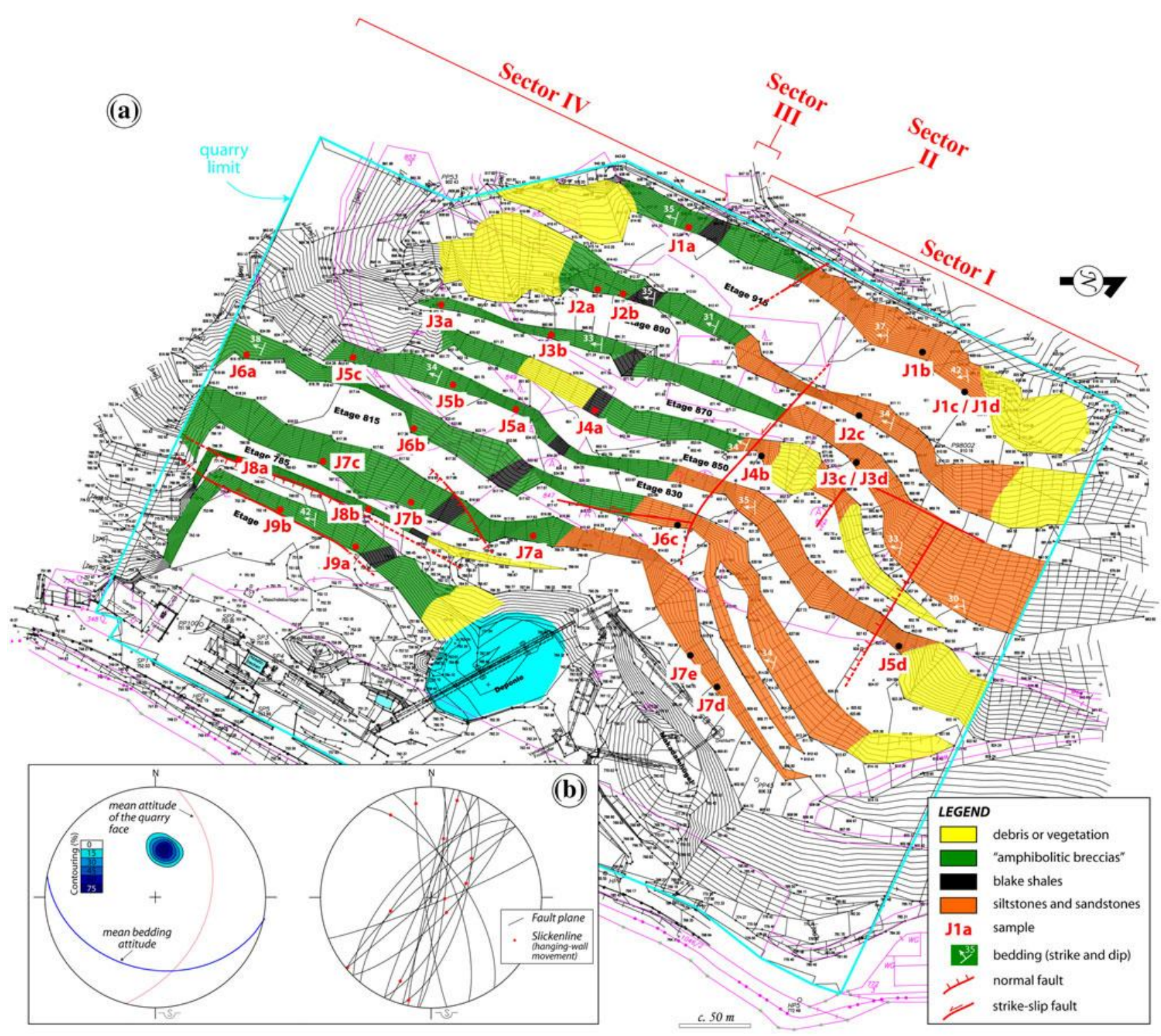

Fig. 3 a Geological map of the quarry area showing the four recognized sectors and distribution of the major fault systems. b Stereographic projections (Schmidt net, lower hemisphere) showing orientation of bedding and major fault systems

\section{Petro-textural analyses}

All the detailed observations were undertaken on both the matrix and the clasts, to better understand the distinctions between mineral fragments (in the matrix) and foliationforming minerals. The mineralogical abbreviations adopted for figures and tables are from Kretz (1983) and Bucher and Frey (2002).

\section{Matrix-dominant texture}

Samples from Sector I (J1b, J1c, J2c, J3d, J5d, J7d, J7e) show a fine-grained matrix (Fig. 6a) mainly consisting of minerals fragments (in order of abundance: chlorite, plagioclase, quartz, epidote, biotite, ilmenite, titanite) with dimensions of less than a few microns. Evidence of bedding is often marked by variation in grain size. Mineral fragments show a regular shape (from tabular to blocky) and vary from sub-rounded to sub-angular. Sporadic clasts are immersed within the matrix. Clasts are both mafic and felsic in composition (Fig. 6b), with the composition maturity (mafic/felsic) about $60 \%$. Mafic clasts are mostly sub-angular, while the sub-rounded shape has been mainly detected for the felsic material. Mafic clasts are characterized by a metamorphic fabric consisting of incipient foliation where chlorite, plagioclase, epidote, quartz, and ilmenite crystallise (mineral accessories: titanite, apatite and hematite). No amphibole has been recognised within the observed samples, in either the matrix, or the clasts. 

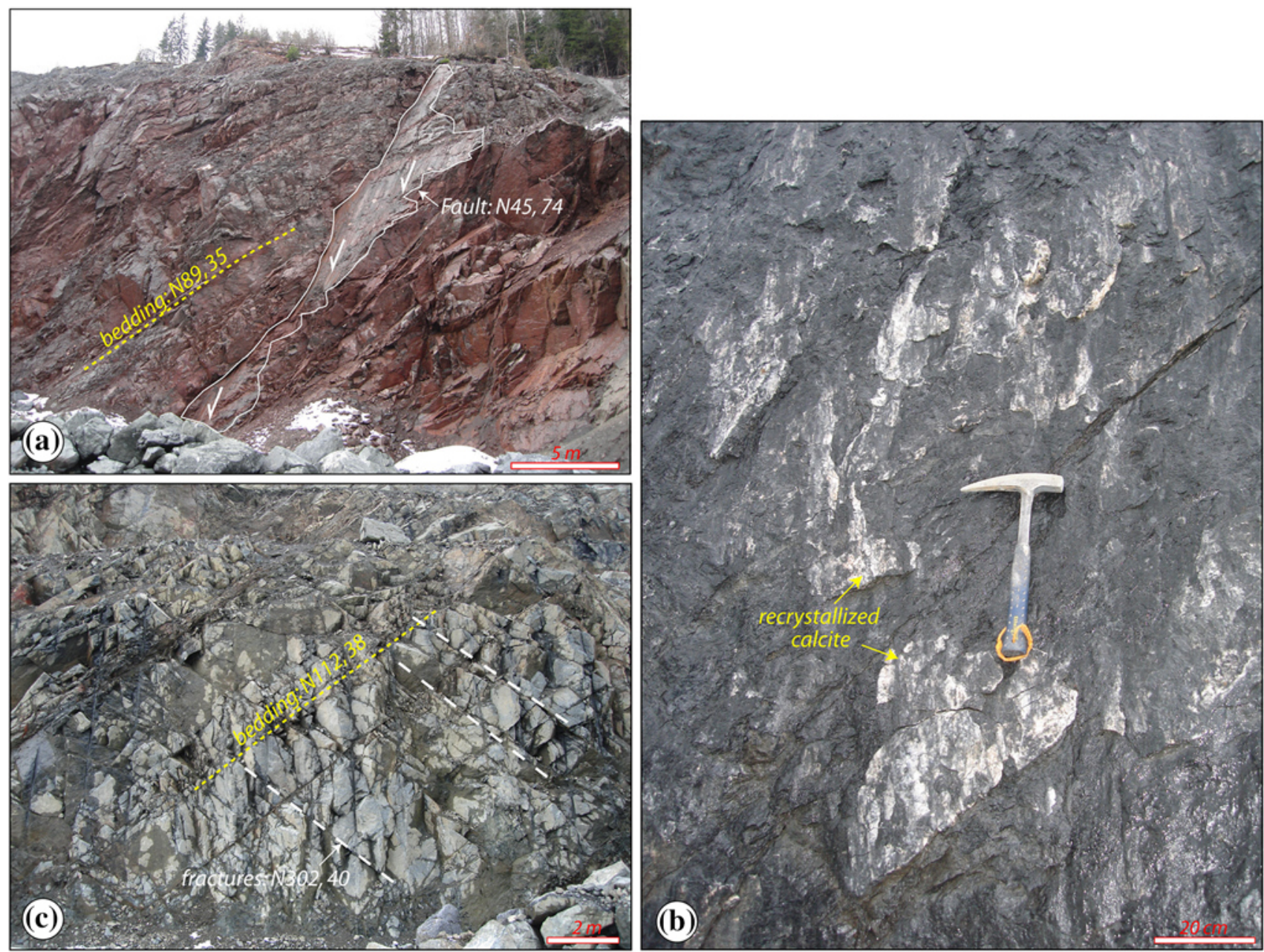

(c)
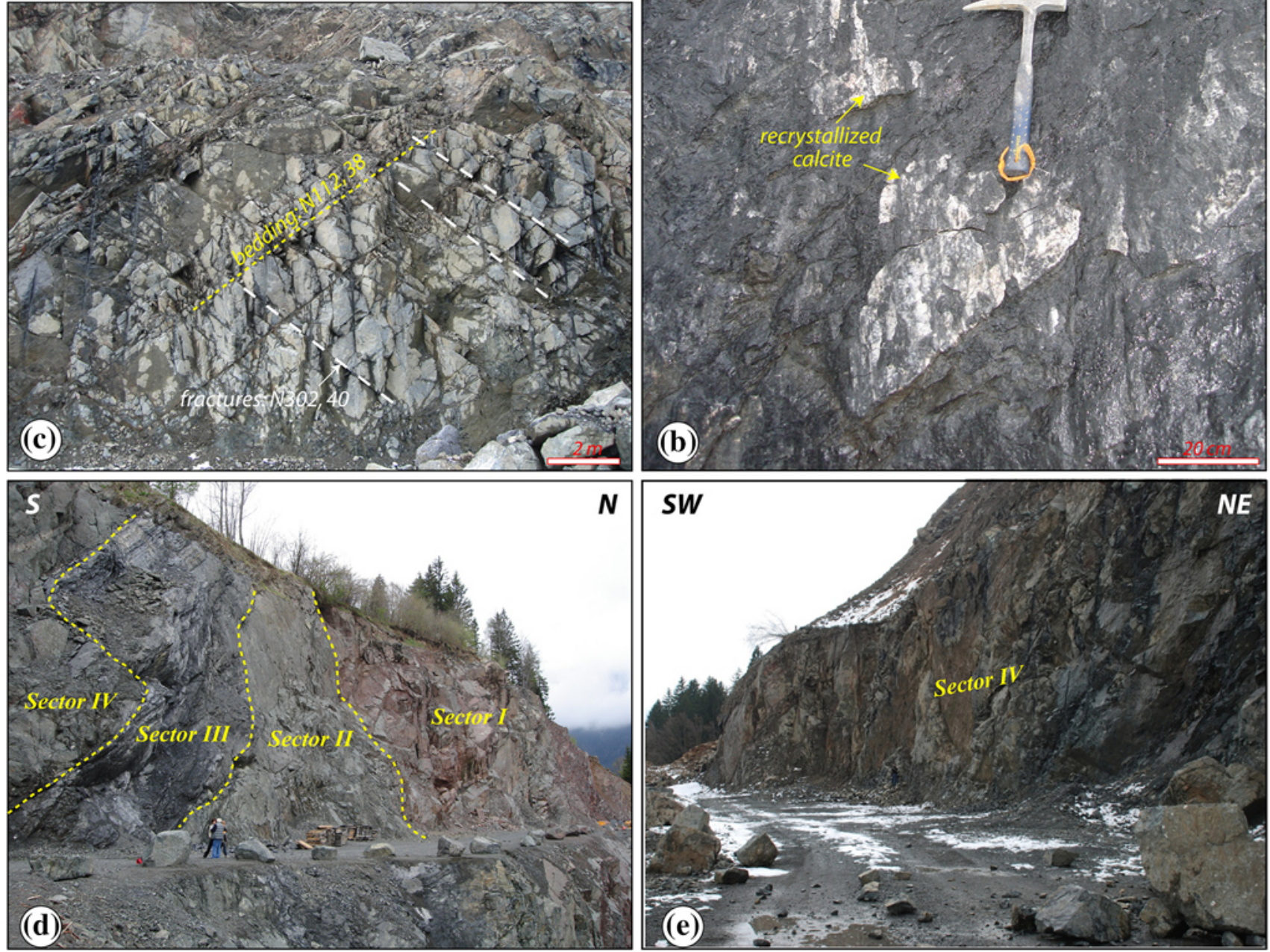

(d)

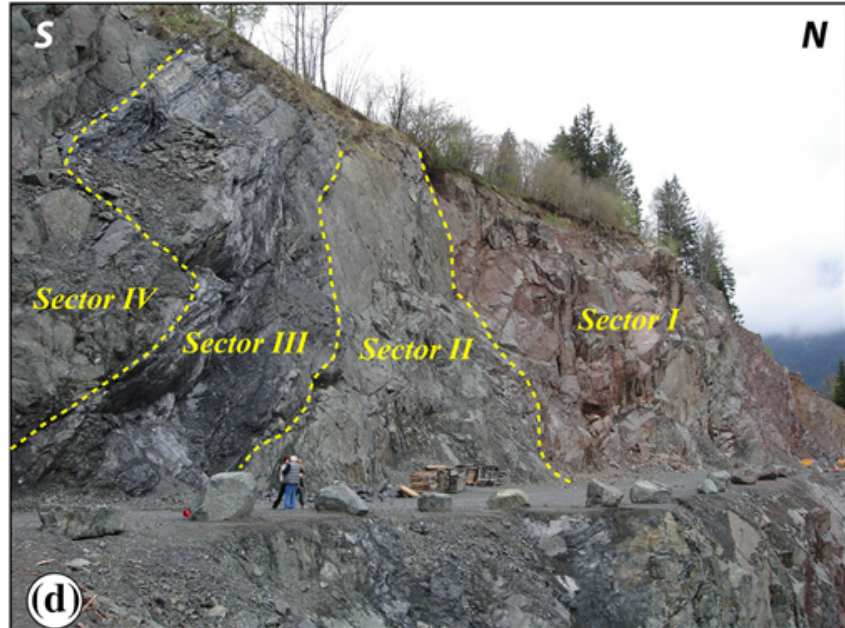

Fig. 4 Field observations. a Fault surface cutting cross the red siltstone member. b Calcite mineralization along the fault surface. c Fracture system involving the original bedding within amphibolitic

Samples from Sector IV (J1a, J3b, J5c, J7b, J7c, J9a) show that the matrix consists of fragments of green amphibole, plagioclase, epidote, quartz, ilmenite, pyroxene, titanite, iron oxides, calcite, and apatite (in order of

breccias. d Panoramic view of the Sectors I, II, and III on bench 900 m.a.s.l. e Panoramic view of Sector IV on bench 850 m.a.s.l

abundance). Mineral fragments have prismatic (mostly amphibole and plagioclase) and rounded (epidote and quartz) shapes (Fig. 6c). The size of the minerals does not exceed $200 \mu \mathrm{m}$, except for a few porphyroclasts of 

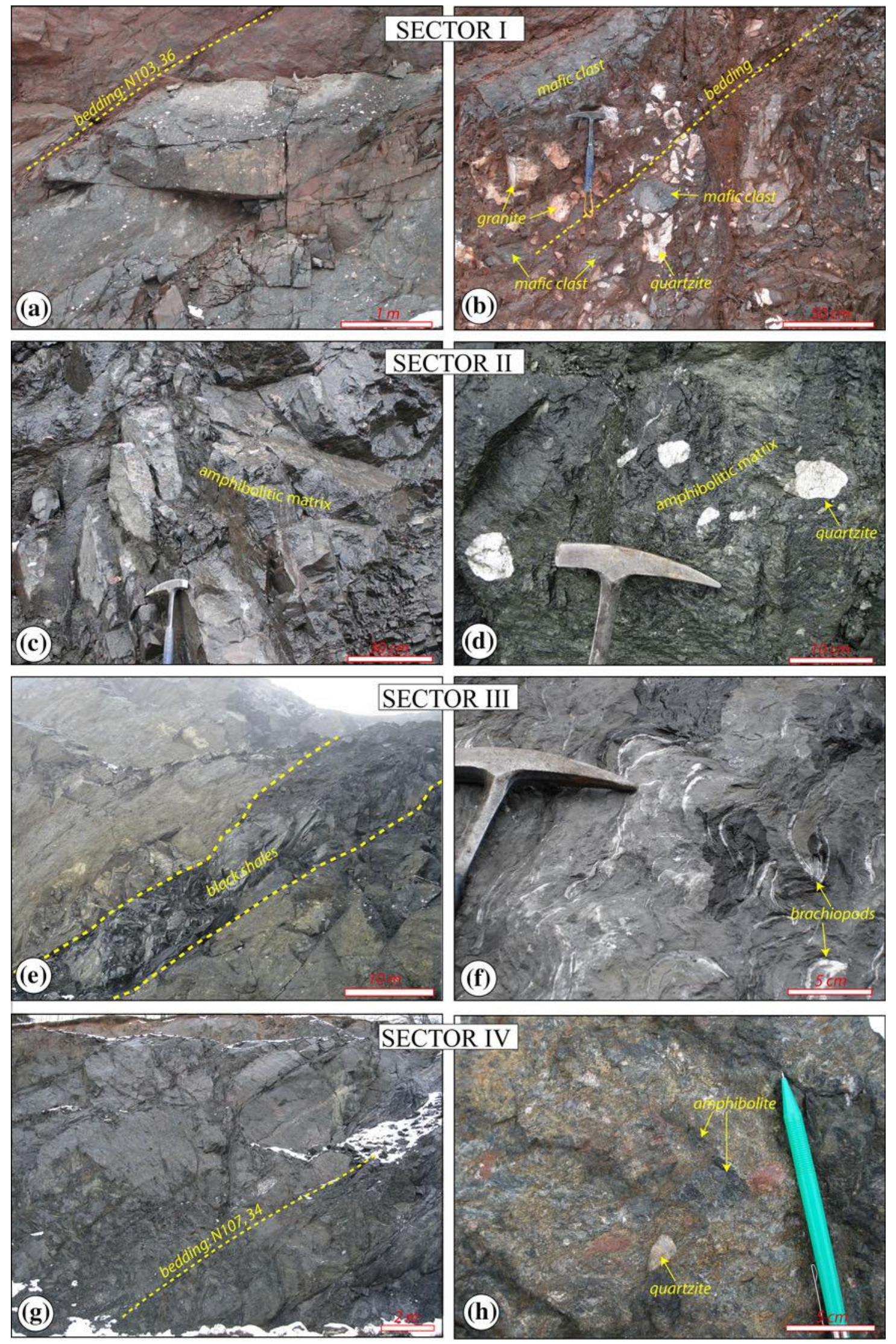
Fig. 5 Meso-scale fabric features. Sector I: a red-coloured siltstones and sandstones evolving to decimetric thick breccias; b mafic and felsic clasts within the red siltstone matrix. Sector II: c greenish matrix with amphibolite pebbles; d quartzitic clasts within the amphibolitic fine-grained matrix. Sector III: e panoramic view of the black shales on the bench 815 m.a.s.l.; f detail of brachiopod moulds within the shales. Sector IV: g metric-spaced bedding within the amphibolitic breccias; $\mathbf{h}$ detail of the texture consisting in pebbles of amphibolites and few quartzites

plagioclase. Alternation of different grain-size layers often defines the bedding (Fig. 6d), in which dispersed clasts of up to $1 \mathrm{~cm}$ can be found.

\section{Clast-dominant texture}

Samples from Sector I (J3c, J4b, J6c) have middle-to-high composition maturity, with mafic clasts up to $90 \%$ of the total, and very low sorting degree. Mafic clasts are well rounded within a fine-grained matrix (Fig. 6e). Internal textures are characterized by pervasive metamorphic schistosity, with micrometric spacing between foliation planes. In samples $\mathrm{J} 3 \mathrm{c}$ and $\mathrm{J} 4 \mathrm{~b}$, the schistosity consists of chlorite-epidote-plagioclase-quartz-ilmenite (plus titanite and hematite as mineral accessories) composite assemblages (Fig. 6f). In sample J6c, the green amphibole-plagioclase-epidote mineralogical association allows the classification of amphibolitic clasts. Sample J1d consists of a single mafic clast enclosed within the siltitic matrix. It shows a metamorphic foliation composed of chlorite-plagioclase-epidote-quartz (typical of metabasites), intersected by micrometric vein sets filled by plagioclase + quartz.

Samples from Sector IV (J2a, J2b, J3a, J5a, J5b, J6a, $\mathrm{J} 6 \mathrm{~b}, \mathrm{~J} 8 \mathrm{a}, \mathrm{J} 8 \mathrm{~b}, \mathrm{~J} 9 \mathrm{~b}$ ) are compositionally dominated by mafic clasts, which constitute about $95 \%$ of the total (Fig. 6g). The remnant $5 \%$ is represented by clasts of granite and quartzite. Mafic clasts show mineralogical assemblages defined by green amphibole, epidote, and plagioclase (plus quartz and ilmenite), which are typical of amphibolite. Rounding varies according to size and shape of clasts, as tabular and large lithics (up to $3 \mathrm{~cm}$ ) are more sub-rounded than the smaller ones. Sorting degree is largely dispersive from $20 \%(\mathrm{~J} 2 \mathrm{a}, \mathrm{J} 2 \mathrm{~b}, \mathrm{~J} 5 \mathrm{a}, \mathrm{J} 5 \mathrm{~b}, \mathrm{~J} 6 \mathrm{a}, \mathrm{J} 6 \mathrm{~b}, \mathrm{~J} 8 \mathrm{~b}, \mathrm{~J} 9 \mathrm{~b})$ to 75-85\% (J3a, J8a). Internal textures are characterized by schistosity in which green amphiboles, plagioclase and epidote (plus quartz and ilmenite as accessories) show relationships of textural equilibrium during crystallization (Fig. 6h). In some cases, amphibole defines up to $90 \%$ of the clast fabric. Few pyroxene crystals can be found as porphyroclasts wrapped by the metamorphic foliation; they can be considered as remnants of the early magmatic mineralogical assemblage.

\section{Mineral chemistry}

XRD data

The XRD analyses of powdered samples are listed in Table 4, while selected XRD traces are illustrated in Fig. 7. The samples have been distinguished on the basis of their provenance within the quarry (sector I, II, III, and IV) and considering the texture type (matrix- or clast- dominant). Minerals detected from both matrix- and clast-dominant textures from Sector I are: epidote, plagioclase (albite), quartz, chlorite, and biotite (Fig. 7a). Ti-bearing phases (ilmenite and titanite) are recurrent, as well as phases due to late alteration (goethite, graphite, calcite). A similar XRD trace has been obtained for the single mafic clast (sample J1d) selected from the matrix (Fig. 7b). Amphibole was identified as an accessory mineral in only two samples (J1b and J6c); see Table 4. Samples from Sector II and IV have mineralogical affinities defined by the systematic occurrence of amphibole, epidote, plagioclase (anorthite), quartz, and chlorite. In particular, for samples from Sector IV (both matrix- and clast-dominated textures), amphibole (hornblende and tschermakite) defines a diagnostic mineralogical constituent, as well as primary magmatic phases represented by pyroxene (augite and diopside) (Fig. 7c). By comparing diffractometric patterns of the selected samples, some differences can be

Table 2 Uniaxial strength (MPa) determined by using a Schmidt hammer (GEOHAMMER model)

\begin{tabular}{|c|c|c|c|c|c|}
\hline \multicolumn{6}{|c|}{ Geological-structural setting of rock volume } \\
\hline \multicolumn{2}{|c|}{ Massive/undeformed } & \multicolumn{2}{|l|}{ Bedded } & \multicolumn{2}{|l|}{ Fractured } \\
\hline & & $10-20 \mathrm{~cm}$ & $5-10 \mathrm{~cm}$ & $>5 \mathrm{~cm}$ & $1-5 \mathrm{~cm}$ \\
\hline \multicolumn{6}{|c|}{ Sector } \\
\hline I & $>200(64 \pm 5)$ & $192(54 \pm 4)$ & $143(46 \pm 5)$ & $150(48 \pm 8)$ & $19(19 \pm 5)$ \\
\hline IV & $>200(66 \pm 7)$ & $>200(58 \pm 5)$ & n.d. & n.d. & n.d. \\
\hline
\end{tabular}

Numbers in parenthesis are the average hardness index (with proper standard deviation) provided by statistical analyses of the measurements n.d. not determined 
Table 3 List of selected samples and laboratory analyses performed

\begin{tabular}{|c|c|c|c|}
\hline Sector & Sample & Texture & $\begin{array}{l}\text { Laboratory analyses } \\
\text { performed }\end{array}$ \\
\hline \multirow[t]{11}{*}{ I } & $\mathrm{J} 1 \mathrm{~b}$ & Matrix-dominant & PTTS; XRD \\
\hline & $\mathrm{J} 1 \mathrm{c}$ & Matrix-dominant & PTTS; EMA; XRD \\
\hline & $\mathrm{J} 1 \mathrm{~d}$ & $\begin{array}{l}\text { Mafic clast in } \\
\text { matrix }\end{array}$ & PTTS; EMA; XRD \\
\hline & $\mathrm{J} 2 \mathrm{c}$ & Matrix-dominant & PTTS; EMA; XRD \\
\hline & $\mathrm{J} 3 \mathrm{c}$ & Clast-dominant & PTTS; EMA; XRD \\
\hline & $\mathrm{J} 3 \mathrm{~d}$ & Matrix-dominant & XRD \\
\hline & $\mathrm{J} 4 \mathrm{~b}$ & Clast-dominant & PTTS; EMA; XRD \\
\hline & $\mathrm{J} 5 \mathrm{~d}$ & Matrix-dominant & PTTS; EMA; XRD \\
\hline & $\mathrm{J} 6 \mathrm{c}$ & Clast-dominant & PTTS; EMA; XRD \\
\hline & $\mathrm{J} 7 \mathrm{~d}$ & Matrix-dominant & PTTS; EMA; XRD \\
\hline & $\mathrm{J} 7 \mathrm{e}$ & Matrix-dominant & XRD \\
\hline II & $\mathrm{J} 7 \mathrm{a}$ & Matrix-dominant & PTTS; XRD \\
\hline III & $\mathrm{J} 4 \mathrm{a}$ & Matrix-dominant & PTTS \\
\hline \multirow[t]{16}{*}{ IV } & $\mathrm{J} 1 \mathrm{a}$ & Matrix-dominant & PTTS; EMA; XRD; SEM \\
\hline & $\mathrm{J} 2 \mathrm{a}$ & Clast-dominant & PTTS; EMA; XRD; SEM \\
\hline & $\mathrm{J} 2 \mathrm{~b}$ & Clast-dominant & PTTS; EMA; XRD \\
\hline & $\mathrm{J} 3 \mathrm{a}$ & Clast-dominant & PTTS; XRD \\
\hline & $\mathrm{J} 3 \mathrm{~b}$ & Matrix-dominant & PTTS; EMA; XRD \\
\hline & $\mathrm{J} 5 \mathrm{a}$ & Clast-dominant & PTTS; EMA; XRD \\
\hline & $\mathrm{J} 5 \mathrm{~b}$ & Clast-dominant & PTTS; XRD \\
\hline & $\mathrm{J} 5 \mathrm{c}$ & Matrix-dominant & PTTS; EMA; XRD \\
\hline & J6a & Clast-dominant & PTTS; EMA; XRD; SEM \\
\hline & $\mathrm{J} 6 \mathrm{~b}$ & Clast-dominant & PTTS; EMA; XRD \\
\hline & $\mathrm{J} 7 \mathrm{~b}$ & Matrix-dominant & PTTS; EMA; XRD \\
\hline & $\mathrm{J} 7 \mathrm{c}$ & Matrix-dominant & PTTS; EMA; XRD \\
\hline & $\mathrm{J} 8 \mathrm{a}$ & Clast-dominant & PTTS; XRD \\
\hline & $\mathrm{J} 8 \mathrm{~b}$ & Clast-dominant & PTTS; EMA; XRD \\
\hline & $\mathrm{J} 9 \mathrm{a}$ & Matrix-dominant & PTTS; EMA; XRD \\
\hline & $\mathrm{J} 9 \mathrm{~b}$ & Clast-dominant & PTTS; EMA; XRD \\
\hline
\end{tabular}

PTTS petro-textural observations on thin section, EMA electron microprobe analyses, $X R D \mathrm{X}$-ray diffractometry, SEM scanning electron microprobe

extrapolated concerning both the mineralogy and the proportion (\%) of a single mineral. In particular, the occurrence of amphibole seems to be diagnostic for samples coming from Sector II and Sector IV, while no evidence for amphibole (excluding sample J6c) has been detected for Sector I. Finally, the proportion (\%) of chlorite and quartz is usually higher (up to one order of magnitude) for samples belonging to Sector I with respect to those from Sector IV (Fig. 7d).

Electron microprobe analyses of amphiboles

Quantitative chemical analyses were performed on amphiboles found both in the matrix- dominant and clastdominant textures. Mineral recalculation and estimation of
Fig. 6 Micro-scale fabric features. Matrix-dominated textures: a thin section (Sector I) illustrating fine-grain matrix; $\mathbf{b}$ detail of mafic clast and granitic clast imbedded within the matrix; c matrix composed by larger plagioclase and epidote fragments and finer amphiboles; d evidence for bedding corresponding to variation of the grain size. Clast-dominated textures: e textural relationships between rounded mafic and felsic clasts; f incipient metamorphic foliation in clast defined by chlorite-epidote-plagioclase-quartz assemblage; $\mathbf{g}$ thin section (Sector IV) illustrating relationship between amphibolitic and granitic clasts; h metamorphic foliation within amphibolitic clast mainly composed by elongated amphiboles (plus plagioclase and epidote). Micro-pictures (c), (f), and (h) are in crossed polars; micropictures (b), (d), and (e) are in natural light. Scale is shown. Abbreviations: $c G$ granitic clast, $c M$ mafic clast, $m$ matrix

$\mathrm{Fe}^{3+}$ contents were made using the WinAmphcal software (Yavuz 2007), normalizing to 15 cations. Groups and amphibole names were considered according to the nomenclature approved by the International Mineralogical Association (Leake et al. 1997, 2004). Representative analyses and the structural formulae of minerals are presented in Table 5 where amphiboles are grouped as grains found in the matrix or within the metamorphic foliation in clasts.

All analysed species are calcic-amphiboles $(\mathrm{CaB}>1.50$; Leake et al. 1997). Both amphiboles (found as fragments in the matrix and amphiboles within the metamorphic foliation in clasts) mainly fall within the Tschermakite $\left(6.50<\mathrm{Si}^{4+}<5.50\right.$ atoms per formula unit; $\left.\mathrm{Mg \#}>0.50\right)$ and $\mathrm{Mg}$-hornblende $\left(7.50<\mathrm{Si}^{4+}<6.50\right.$ atoms per formula unit; $\mathrm{Mg} \#>0.50$ ) fields (where $\mathrm{Mg} \#=\mathrm{Mg} /\left[\mathrm{Mg}+\mathrm{Fe}^{2+}\right]$; Fig. 8a). Amphiboles in a clast-dominant texture show a more dispersive composition spanning into the Fe-hornblende $\left(7.50<\mathrm{Si}^{4+}<6.50\right.$ atoms per formula unit; $\mathrm{Mg \#}<$ $0.50)$ and the actinolite $\left(8.00<\mathrm{Si}^{4+}<7.50\right.$ atoms per formula unit; $0.50<\mathrm{Mg} \#<0.90$ ) fields (Fig. 8b). No mineral zoning has been observed within single grains.

\section{Morphological analysis}

The morphological analysis has been performed on samples from Sector IV where a large amount of amphibole occurs. Amphiboles from both matrix- (sample J1a) and clast- dominant textures (samples J2a and J6a) have been observed. Under the optical polarizing microscope, the amphiboles appear a dark-greenish colour, with a pleochroism from light green to greenish-brown, and homogeneous extinction under crossed polarized light. Amphiboles within the matrix (sample J1a) show a tabular/prismatic morphological habit (Fig. 9a, b), with evidence of mechanical cleavage probably related to fragmentation. Perfect prismatic crystals of hornblende (up to $0.5 \mathrm{~mm}$ in size) characterized by two cleavage directions intersecting at roughly $60^{\circ}$ and $120^{\circ}$ can also be observed in the fine 

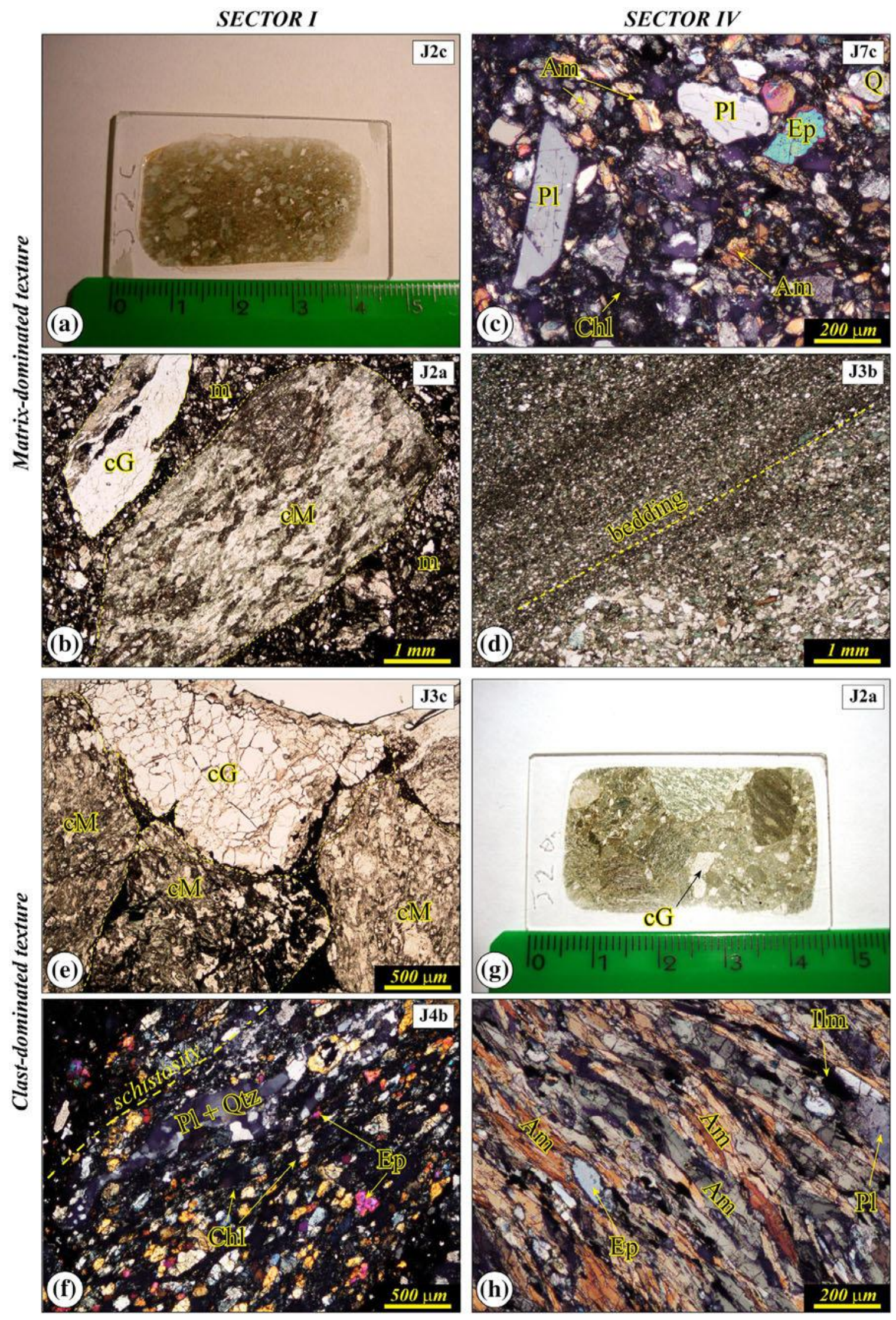
Table 4 List of mineral species identified by X-ray diffractometry

\begin{tabular}{|c|c|c|c|c|c|c|c|c|c|c|}
\hline Sector & Texture & Sample & Pyroxene & Amphibole & Epidote & Plagioclase & Quartz & Chlorite & Biotite & Accessories \\
\hline \multirow[t]{11}{*}{ I } & \multirow[t]{7}{*}{ Matrix-dominant } & $\mathrm{J} 1 \mathrm{~b}$ & & $\mathrm{Hbl}$ ? & & & $\mathrm{X}$ & $\mathrm{X}$ & & Gr \\
\hline & & $\mathrm{J} 1 \mathrm{c}$ & & & Czo & $\mathrm{Ab}$ & $X$ & $X$ & $X$ & \\
\hline & & $\mathrm{J} 2 \mathrm{c}$ & & & Czo & $\mathrm{Ab}$ & $\mathrm{X}$ & $\mathrm{X}$ & $\mathrm{X}$ & $\mathrm{Cal}$ \\
\hline & & $\mathrm{J} 3 \mathrm{~d}$ & & & Czo & $\mathrm{Ab}$ & $\mathrm{X}$ & $X$ & $X$ & Ill, Ttn \\
\hline & & $\mathrm{J} 5 \mathrm{~d}$ & & & Czo & $\mathrm{Ab}$ & & $\mathrm{X}$ & & \\
\hline & & $\mathrm{J} 7 \mathrm{~d}$ & & & Czo & $\mathrm{Ab}$ & $\mathrm{X}$ & $X$ & & \\
\hline & & $\mathrm{J} 7 \mathrm{e}$ & & & Czo & $\mathrm{Ab}$ & & $\mathrm{X}$ & & Gt, Ttn \\
\hline & \multirow[t]{4}{*}{ Clast-dominant } & J1d & & & Ep & $\mathrm{Ab}$ & $\mathrm{X}$ & & & Gt \\
\hline & & $\mathrm{J} 3 \mathrm{c}$ & & & Ep & $\mathrm{Ab}$ & & $\mathrm{X}$ & & \\
\hline & & $\mathrm{J} 4 \mathrm{~b}$ & & & Ep & $\mathrm{Ab}$ & $\mathrm{X}$ & $\mathrm{X}$ & $\mathrm{X}$ & Ttn \\
\hline & & J6c & & Ts & & $\mathrm{Ab}$ & & $\mathrm{X}$ & $\mathrm{X}$ & \\
\hline II & Matrix-dominant & $\mathrm{J} 7 \mathrm{a}$ & & $\mathrm{Hbl}$ & Ep & An & $\mathrm{X}$ & $\mathrm{X}$ & & \\
\hline \multirow[t]{16}{*}{ IV } & \multirow[t]{6}{*}{ Matrix-dominant } & $\mathrm{J} 1 \mathrm{a}$ & Aug & $\mathrm{Hbl}$ & Czo & An & $\mathrm{X}$ & $\mathrm{X}$ & & $\mathrm{Zrn}$ \\
\hline & & $\mathrm{J} 3 \mathrm{~b}$ & Aug & $\mathrm{Hbl}$ & Czo & An & $\mathrm{X}$ & $\mathrm{X}$ & & \\
\hline & & $\mathrm{J} 5 \mathrm{c}$ & & $\mathrm{Hbl}$ & Ep & An & $\mathrm{X}$ & $\mathrm{X}$ & & Cal \\
\hline & & $\mathrm{J} 7 \mathrm{~b}$ & & $\mathrm{Hbl}$ & Ep & An & $X$ & $X$ & & $\mathrm{Cal}$ \\
\hline & & $\mathrm{J} 7 \mathrm{c}$ & & $\mathrm{Hbl}$ & Ep & An & $\mathrm{X}$ & $\mathrm{X}$ & & $\mathrm{Cal}$ \\
\hline & & $\mathrm{J} 9 \mathrm{a}$ & & $\mathrm{Hbl}$ & Ep & An & $\mathrm{X}$ & $\mathrm{X}$ & & $\mathrm{Cal}$ \\
\hline & \multirow[t]{10}{*}{ Clast-dominant } & $\mathrm{J} 2 \mathrm{a}$ & Aug & $\mathrm{Fe}-\mathrm{Hbl}$ & Czo & An & $\mathrm{X}$ & $\mathrm{X}$ & & Zrn \\
\hline & & $\mathrm{J} 2 \mathrm{~b}$ & Di & $\mathrm{Hbl}, \mathrm{Ts}$ & & & $\mathrm{X}$ & $X$ & & Gr, Gt, Mag \\
\hline & & $\mathrm{J} 3 \mathrm{a}$ & Aug, Di & $\mathrm{Fe}-\mathrm{Hbl}, \mathrm{Ts}$ & & An & $\mathrm{X}$ & $\mathrm{X}$ & & $\mathrm{Zrn}$ \\
\hline & & $\mathrm{J} 5 \mathrm{a}$ & & $\mathrm{Hbl}$ & & An & $\mathrm{X}$ & $X$ & & Cal \\
\hline & & $\mathrm{J} 5 \mathrm{~b}$ & & $\mathrm{Hbl}$ & & An & $X$ & $\mathrm{X}$ & & Cal \\
\hline & & J6a & Di & $\mathrm{Fe}-\mathrm{Hbl}, \mathrm{Ts}$ & Czo & An & $\mathrm{X}$ & $\mathrm{X}$ & & $\mathrm{Zrn}$ \\
\hline & & $\mathrm{J} 6 \mathrm{~b}$ & Aug, Di & Ts & Czo & An & $\mathrm{X}$ & $\mathrm{X}$ & & Mag, Zrn \\
\hline & & $\mathrm{J} 8 \mathrm{a}$ & & $\mathrm{Hbl}$ & Ep & An & $\mathrm{X}$ & $\mathrm{X}$ & & $\mathrm{Cal}$ \\
\hline & & $\mathrm{J} 8 \mathrm{~b}$ & & $\mathrm{Hbl}$ & Ep & An & $X$ & $\mathrm{X}$ & & $\mathrm{Cal}$ \\
\hline & & $\mathrm{J} 9 \mathrm{~b}$ & & $\mathrm{Hbl}$ & Ep & An & $X$ & $X$ & & $\mathrm{Cal}$ \\
\hline
\end{tabular}

$\overline{A b}$ albite, $A n$ anorthite, $A u g$ augite, $C a l$ calcite, $C h l$ clinochlore, $C z o$ clinozoisite, $D i$ diopside, $E p$ epidote, $G t$ goethite, $G r$ graphite, $H b l$ hornblende, Mag magnetite, $T s$ tschermakite, $Z r n$ zircon

matrix (Fig. 9b). Amphiboles aligned along the metamorphic foliation in clasts (samples $\mathrm{J} 2 \mathrm{a}$ and $\mathrm{J} 6 \mathrm{a}$ ) show a similar tabular/prismatic habit, slightly evolving into a lanceolar one (Fig. 9c,d). Edges of amphiboles are texturally in contact with other metamorphic minerals (epidote, albite, and chlorite) suggesting crystallization during development of foliation.

SEM-BSE images show a homogeneous chemical pattern, confirming that no chemical zoning occurred during crystallization and growth of amphibole. Minerals do not show evidence of chemical resorption, neither along the internal cleavages nor at the external edges. The aspect ratio has been calculated as ranging between 2 and 9, with no substantial differences between hornblende and tschermakite grains (Fig. 9a). Actinolite grains (sample J2a) have aspect ratios ranging between 2 and 7 (Fig. 9c) and no evidence for fibrous cleavage was observed in the selected samples. SEM investigations did not reveal the occurrence of amphibole grains showing $<3 \mu \mathrm{m}$ width.

\section{Discussion}

Within the quarry site, a part of the Badstub Formation is exposed, consisting of a stratified succession of amphibolitic breccias with intercalated sandstones, siltstones and shales. On the basis of the geological-structural survey and the determination of the lithology, mechanical strength and petro-structural features, it is possible to distinguish four main zones within this flyschoid sequence which, it is considered, identify four commercial sectors in the quarry. The transition between adjacent sectors is always marked by a stratigraphic boundary that can be mapped continuously all along the quarry levels. Sectors I 

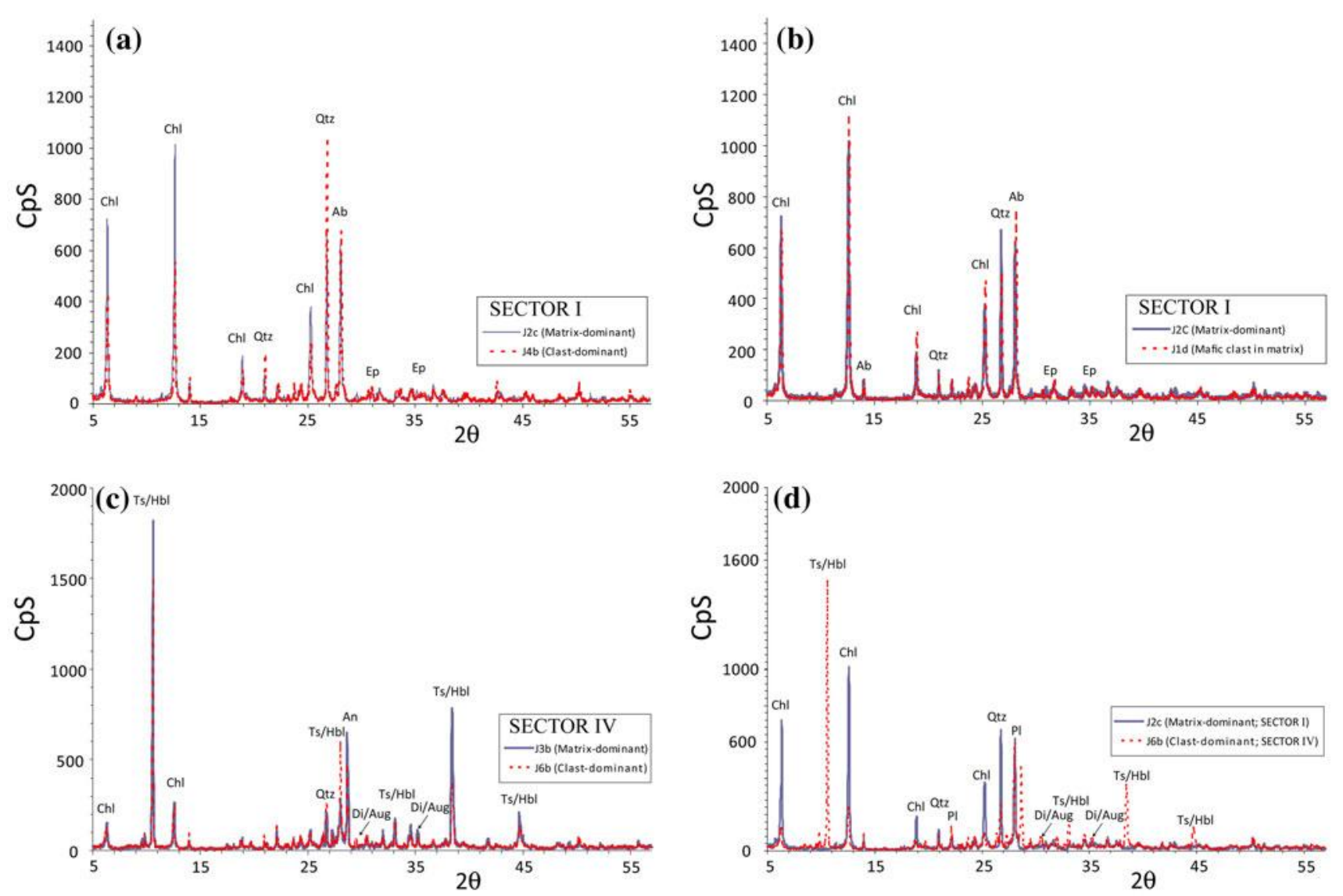

Fig. 7 Selected XRD patterns for: a matrix- and clast-dominated textures from Sector I; $\mathbf{b}$ matrix-dominated textures and mafic clast from Sector I; c matrix- and clast- dominated textures from Sector IV;

and IV have slope faces some hundred metres wide allowing selective production of material with similar properties. Both the NE-SW and the NW-SE fault systems cut all along the stratigraphy, with centimetre to metre displacements. Faults are not widely dispersed, but they define localised structures that can be mapped in detail. Fractures are intimately connected with the major fault systems, with $10-20 \mathrm{~cm}$ wide broken zones at the main faults.

Geometric criteria describing discontinuities in a rock mass (I.S.R.M. 1978), including orientation, spacing, and persistence, are informative prerequisites (1) to discriminate conditions of slope stability and (2) to maximise economic benefits. Although kinematic analysis is not the aim of the paper, some peculiar geological conditions are recognised which could induce block failure in slopes:

1. the sets of normal faults in Sector IV that dip out of the slope and strike parallel to the face;

2. the stratigraphic boundaries between adjacent sectors that correspond to a change in rock properties;

d comparison between matrix-dominated texture (Sector I) and clastdominated texture (Sector IV)

3. the south-dipping bedding of the strata when it daylights in benches during the eastward propagation of the excavation.

Meso-scale geological-stratigraphic observations, combined with geomechanical characteristics, suggest that rock masses excavated from Sectors I, II, and IV can be considered as material suitable for railway ballast, roadbed and other engineering infrastructures. The data indicate that both faults and bedding constitute first-order discontinuities controlling the size of the blocks that can be excavated. The persistence of laminated horizons in Sector I facilitate the production of small size blocks, while the metre-size blocks require more extensive milling and grinding in Sector IV. In addition, the Schmidt hammer results indicate the rock strength in Sector I is progressively reduced as the fracturing is more intense and comminution is common.

Selected samples from Sector IV show that the rock mass is characterized by the occurrence of amphiboles, pyroxene and anorthite while in Sector I albite and biotite can be considered diagnostic. The petrology, together with textural features, affects the quality of the processed 
Table 5 Representative electron microprobe analyses of amphibole

\begin{tabular}{|c|c|c|c|c|c|c|c|c|c|c|c|c|c|c|c|c|}
\hline \multirow{4}{*}{$\begin{array}{l}\text { Sector } \\
\text { Sample } \\
\text { Texture } \\
\text { Analysis }\end{array}$} & & \multicolumn{12}{|l|}{ IV } \\
\hline & & & & & \multirow{2}{*}{\multicolumn{2}{|c|}{$\frac{\mathrm{J} 1 \mathrm{a}}{\mathrm{m}}$}} & \multirow{2}{*}{\multicolumn{2}{|c|}{$\frac{\mathrm{J} 2 \mathrm{a}}{\mathrm{c}}$}} & \multirow{2}{*}{\multicolumn{2}{|c|}{$\frac{\mathrm{J} 5 \mathrm{a}}{\mathrm{m}}$}} & \multirow{2}{*}{\multicolumn{2}{|c|}{$\frac{\mathrm{J} 6 \mathrm{a}}{\mathrm{c}}$}} & \multirow{2}{*}{\multicolumn{2}{|c|}{$\frac{\mathrm{J} 7 \mathrm{~b}}{\mathrm{~m}}$}} & \multirow{2}{*}{\multicolumn{2}{|c|}{$\frac{\mathrm{J} 8 \mathrm{~b}}{\mathrm{c}}$}} \\
\hline & \multicolumn{2}{|l|}{$\mathrm{m}$} & \multicolumn{2}{|l|}{$\mathrm{c}$} & & & & & & & & & & & & \\
\hline & C1_a8 & C1_a9 & C1_a5 & C1_a6 & C3_a1 & C3_a2 & C2_a1 & C2_a4 & C1_a4 & C2_a1 & C2_a1 & C5_a3 & C1_a4 & & C1_a3 & C1_a4 \\
\hline $\mathrm{SiO}_{2}$ & 44.94 & 42.83 & 43.74 & 44.06 & 44.35 & 41.55 & 54.81 & 42.82 & 44.85 & 43.99 & 43.97 & 46.4 & 43.49 & 44.42 & 45.52 & 43.78 \\
\hline $\mathrm{TiO}_{2}$ & 0.4 & 0.56 & 0.6 & 0.62 & 0.16 & 0.47 & 0.01 & 0.4 & 0.43 & 0.65 & 0.7 & 0.4 & 0.38 & 0.52 & 0.41 & 0.4 \\
\hline $\mathrm{Al}_{2} \mathrm{O}_{3}$ & 10.36 & 11 & 10.72 & 11.57 & 11.97 & 13.06 & 2.39 & 11.09 & 11.55 & 11.83 & 11.17 & 10.66 & 10.92 & 12.55 & 11.22 & 13.85 \\
\hline $\mathrm{Cr}_{2} \mathrm{O}_{3}$ & 0.05 & 0 & 0.01 & 0.02 & 0.06 & 0 & 0.04 & 0.07 & 0.08 & 0.01 & 0.04 & 0.03 & 0.01 & 0 & 0 & 0.03 \\
\hline $\mathrm{FeO}$ & 13.88 & 17.52 & 17.16 & 14.44 & 18.95 & 17.97 & 11.63 & 18.37 & 17 & 19.02 & 18.14 & 13.43 & 20.68 & 19.56 & 15.81 & 15.58 \\
\hline $\mathrm{MnO}$ & 0.27 & 0.31 & 0.36 & 0.35 & 0.31 & 0.36 & 0.27 & 0.28 & 0.32 & 0.41 & 0.43 & 0.22 & 0.42 & 0.32 & 0.25 & 0.25 \\
\hline $\mathrm{MgO}$ & 12.23 & 9.94 & 10.54 & 11.93 & 9.56 & 9.57 & 16.83 & 11.34 & 10.43 & 9.48 & 10.18 & 12.98 & 9.28 & 7.78 & 12.41 & 10.91 \\
\hline $\mathrm{CaO}$ & 11.97 & 12.02 & 9.39 & 11.32 & 7.87 & 11.45 & 12.48 & 10.48 & 12.12 & 11.63 & 11.64 & 12.39 & 11.49 & 10.79 & 11.22 & 11.3 \\
\hline $\mathrm{Na}_{2} \mathrm{O}$ & 1.24 & 1.28 & 1.27 & 1.75 & 1.17 & 1.46 & 0.27 & 1.16 & 1.27 & 1.6 & 1.5 & 1.29 & 1.37 & 2.09 & 1.48 & 1.58 \\
\hline $\mathrm{K}_{2} \mathrm{O}$ & 0.14 & 0.52 & 0.95 & 0.19 & 0.21 & 0.41 & 0.06 & 0.23 & 0.3 & 0.14 & 0.5 & 0.17 & 0.49 & 0.64 & 0.24 & 0.38 \\
\hline Total & 97.51 & 97.98 & 96.68 & 98.28 & 96.58 & 98.31 & 98.78 & 98.24 & 98.35 & 98.75 & 98.27 & 97.97 & 98.54 & 98.67 & 98.55 & 98.06 \\
\hline $\mathrm{Si}$ & 6.64 & 6.42 & 6.66 & 6.47 & 6.75 & 6.2 & 7.73 & 6.35 & 6.53 & 6.42 & 6.45 & 6.66 & 6.41 & 6.57 & 6.54 & 6.34 \\
\hline $\mathrm{Ti}$ & 0.05 & 0.06 & 0.07 & 0.07 & 0.02 & 0.05 & 0 & 0.05 & 0.05 & 0.07 & 0.08 & 0.04 & 0.04 & 0.06 & 0.05 & 0.04 \\
\hline $\mathrm{Al}$ & 1.8 & 1.9 & 1.9 & 2 & 2.15 & 2.3 & 0.4 & 1.94 & 1.98 & 2.03 & 1.93 & 1.8 & 1.9 & 2.19 & 1.9 & 2.36 \\
\hline $\mathrm{Cr}$ & 0.01 & 0 & 0 & 0 & 0.01 & 0 & 0.01 & 0.01 & 0.01 & 0 & 0.01 & 0 & 0 & 0.43 & 0 & 0 \\
\hline $\mathrm{Fe}^{3+}$ & 0.8 & 0.98 & 0.42 & 0.88 & 0.26 & 1.12 & 0.12 & 1.21 & 0.81 & 0.95 & 0.92 & 0.76 & 1.1 & 0 & 0.88 & 0.79 \\
\hline $\mathrm{Fe}^{2+}$ & 0.92 & 1.21 & 1.76 & 0.9 & 2.15 & 1.12 & 1.25 & 1.07 & 1.26 & 1.37 & 1.3 & 0.85 & 1.45 & 1.99 & 1.02 & 1.1 \\
\hline $\mathrm{Mn}^{2+}$ & 0.03 & 0.04 & 0.05 & 0.04 & 0.04 & 0.05 & 0.03 & 0.04 & 0.04 & 0.05 & 0.05 & 0.03 & 0.05 & 0.04 & 0.03 & 0.03 \\
\hline $\mathrm{Mg}$ & 2.69 & 2.22 & 2.39 & 2.61 & 2.17 & 2.13 & 3.54 & 2.51 & 2.26 & 2.06 & 2.22 & 2.78 & 2.04 & 1.72 & 2.66 & 2.36 \\
\hline $\mathrm{Ca}$ & 1.89 & 1.93 & 1.53 & 1.78 & 1.28 & 1.83 & 1.89 & 1.67 & 1.89 & 1.82 & 1.83 & 1.9 & 1.81 & 1.71 & 1.73 & 1.75 \\
\hline $\mathrm{Na}$ & 0.36 & 0.37 & 0.38 & 0.5 & 0.34 & 0.42 & 0.07 & 0.33 & 0.36 & 0.45 & 0.43 & 0.36 & 0.39 & 0.6 & 0.41 & 0.44 \\
\hline K & 0.03 & 0.1 & 0.18 & 0.04 & 0.04 & 0.08 & 0.01 & 0.04 & 0.06 & 0.03 & 0.09 & 0.03 & 0.09 & 0.12 & 0.04 & 0.07 \\
\hline Total & 15.21 & 15.29 & 15.37 & 15.29 & 15.21 & 15.29 & 15.05 & 15.21 & 15.24 & 15.26 & 15.31 & 15.21 & 15.29 & 15.42 & 15.25 & 15.29 \\
\hline Mg\# & 0.75 & 0.65 & 0.58 & 0.75 & 0.5 & 0.66 & 0.74 & 0.7 & 0.64 & 0.6 & 0.63 & 0.77 & 0.58 & 0.46 & 0.72 & 0.68 \\
\hline Name & $\begin{array}{l}\mathrm{Mg}- \\
\mathrm{Hbl}\end{array}$ & Ts & $\begin{array}{l}\mathrm{Mg}- \\
\mathrm{Hbl}\end{array}$ & Ts & $\begin{array}{l}\mathrm{Mg}_{-} \\
\mathrm{Hbl}\end{array}$ & Ts & Act & Ts & $\begin{array}{l}\mathrm{Mg}_{-} \\
\mathrm{Hbl}\end{array}$ & Ts & Ts & $\begin{array}{l}\mathrm{Mg}_{-} \\
\mathrm{Hbl}\end{array}$ & Ts & $\begin{array}{l}\mathrm{Fe}- \\
\mathrm{Hbl}\end{array}$ & $\begin{array}{l}\mathrm{Mg}_{-} \\
\mathrm{Hbl}\end{array}$ & Ts \\
\hline
\end{tabular}

$\mathrm{Mg} \#=\mathrm{Mg} /\left(\mathrm{Mg}+\mathrm{Fe}^{2+}\right) ; \mathrm{m}=$ amphibole found in matrix; $\mathrm{c}=$ amphibole found within clast texture

material used for railway ballast and road sub-base. These minero-petrographic fingerprints provide a clear indication of the specific commercial use of the different sectors within the quarry.

The asbestos assessment and legislation

Minero-petrographic information from selected samples indicates that amphibole is a key mineral of the rocks in Sectors II and Sector IV. Sample J6c belonging to Sector I, where amphibole has been also detected, may correspond to the stratigraphic transition to Sector II, hence asbestos occurrence may involve only the rock mass in Sector II and Sector IV. Minero-petrographic investigations, as well as mineral chemistry and morphology, do not show significant variations in amphiboles matrix- or clast-dominant textures. Chemically, the majority of the amphiboles fall within the Mg-hornblende/tschermakite field (Leake et al. 1997), with few actinolite grains (see also data in Krainer and Mogessie 1991). Size characteristics detected by SEMBSE images for each amphibole type do not provide evidence for a fibrous morphological habit while the aspect ratios are lower than those reported in the literature for amphibole asbestos-induced mesothelioma (e.g. Churg and Wiggs 1984).

Italian Government regulations concerning asbestosbearing rocks (e.g. Ministerial Decree No 178, 14 May 1996; Table 1) imply rigorous quality control of the minero-petrographic characters of the whole rock before and during excavation. However, two points require further consideration:

1. The chemical characterization of amphiboles is not sufficient to define them in terms of asbestos risk. As shown here, for example, actinolite species can be 
Fig. 8 Diagram classifications (after Leake et al. 1997, redrawn) for amphiboles found in matrix (a) and within the amphibolitic clasts (b)
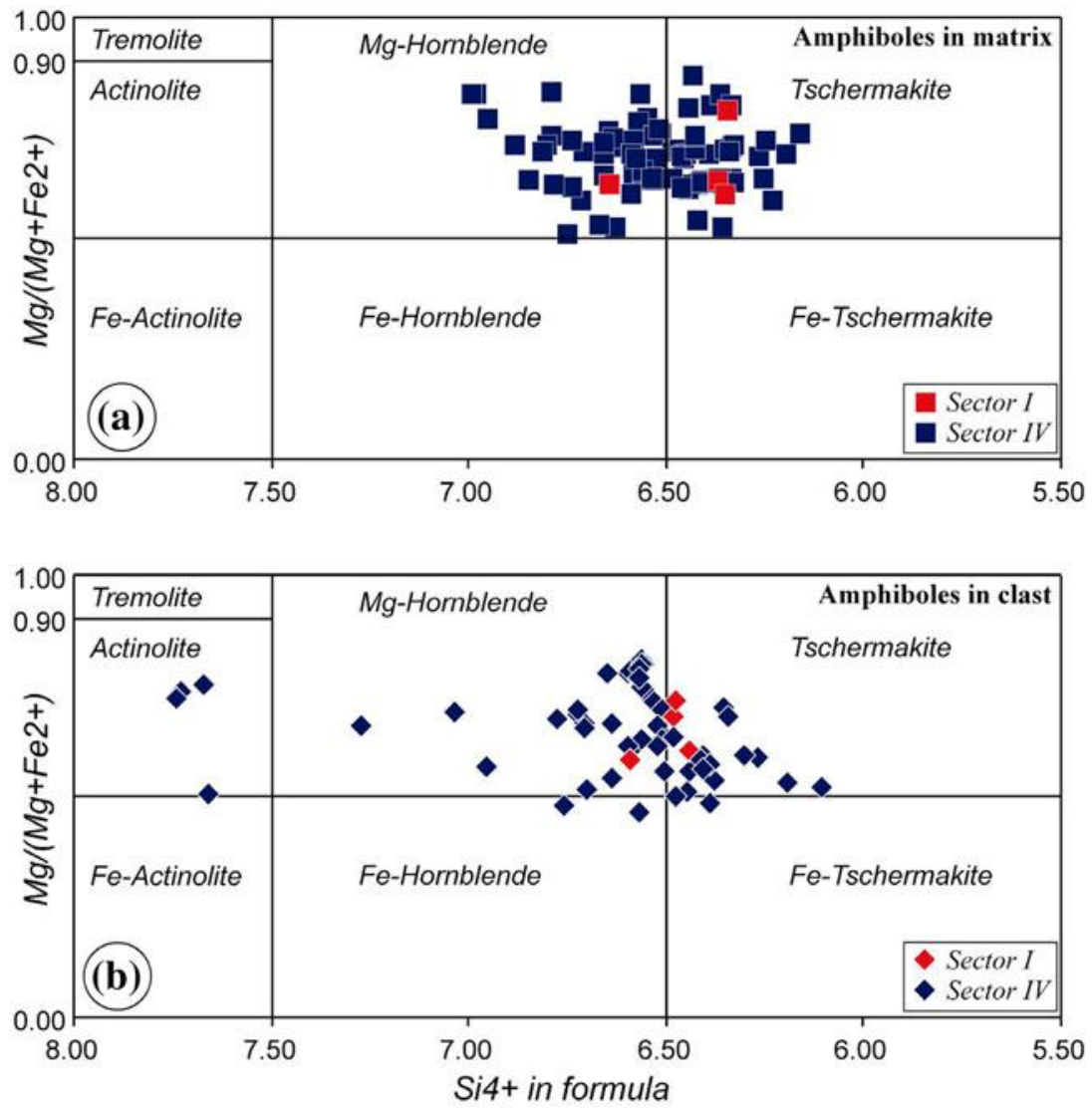

characterized by their prismatic/tabular textural habit, which is not associated with risk to human health. The morphological characterization (at different scales of observation) is essential when considering whether amphibole (or another mineral) shows fibrous cleavage. It must be appreciated that particular geological conditions promote the crystallization of high-strained shape (fibrous) minerals, i.e. ductile-to-brittle deformed structures and the circulation of external fluids which originated during Alpine orogenic metamorphism (e.g. Trommsdorff and Evans 1974; Karkanas 1995; Andreani et al. 2005; Compagnoni and Groppo 2006; Hirauchi and Yamaguchi 2007; Spear 1993). It is suggested that tectono-metamorphic conditions during the Variscan events were not sufficient to result in the formation of fibrous amphiboles;

2. The term "greenstones" has no petrographic validity and it should not be used by regulatory agencies concerning rock quality control. Green-coloured rocks (like amphibolites) are not directly connected with the occurrence of asbestos. More advanced and modern petrographic classification (mainly based on the rock fabric characterization) should be used to reduce ambiguities in the evaluation of asbestos. The flow chart in Fig. 10 compares the rationale from the Italian legislation (based on the "greenstones" terminology) and the proposed methodology. The latter implies that the geologicalstructural surveys constitute the basic tool to elucidate the first- and second-order structures (e.g. ductile and brittle deformation structures) that characterize a quarry site within an ophiolitic rock sequence. Then, determination of the fabric properties of selected samples (representative of the different geological-structural conditions observed) should be undertaken prior to analyses of the mineral chemistry and morphology. The integration of the results allows a classification of the ophiolitic rock in terms of asbestos occurrence, which can inform the quarry activity. Such an approach provides a scientific basis for understanding the geological factors which favour asbestiform mineral formation. Further specific techniques can also be used to determine the size characteristics of the free particles (Harper et al. 2008; Van Orden et al. 2008) and the amount of asbestos likely to be released during grinding (Belardi et al. 2008).

\section{Conclusions}

The case study from an active quarrying site at Carinthia, Austria, illustrates that a detailed geological database is 

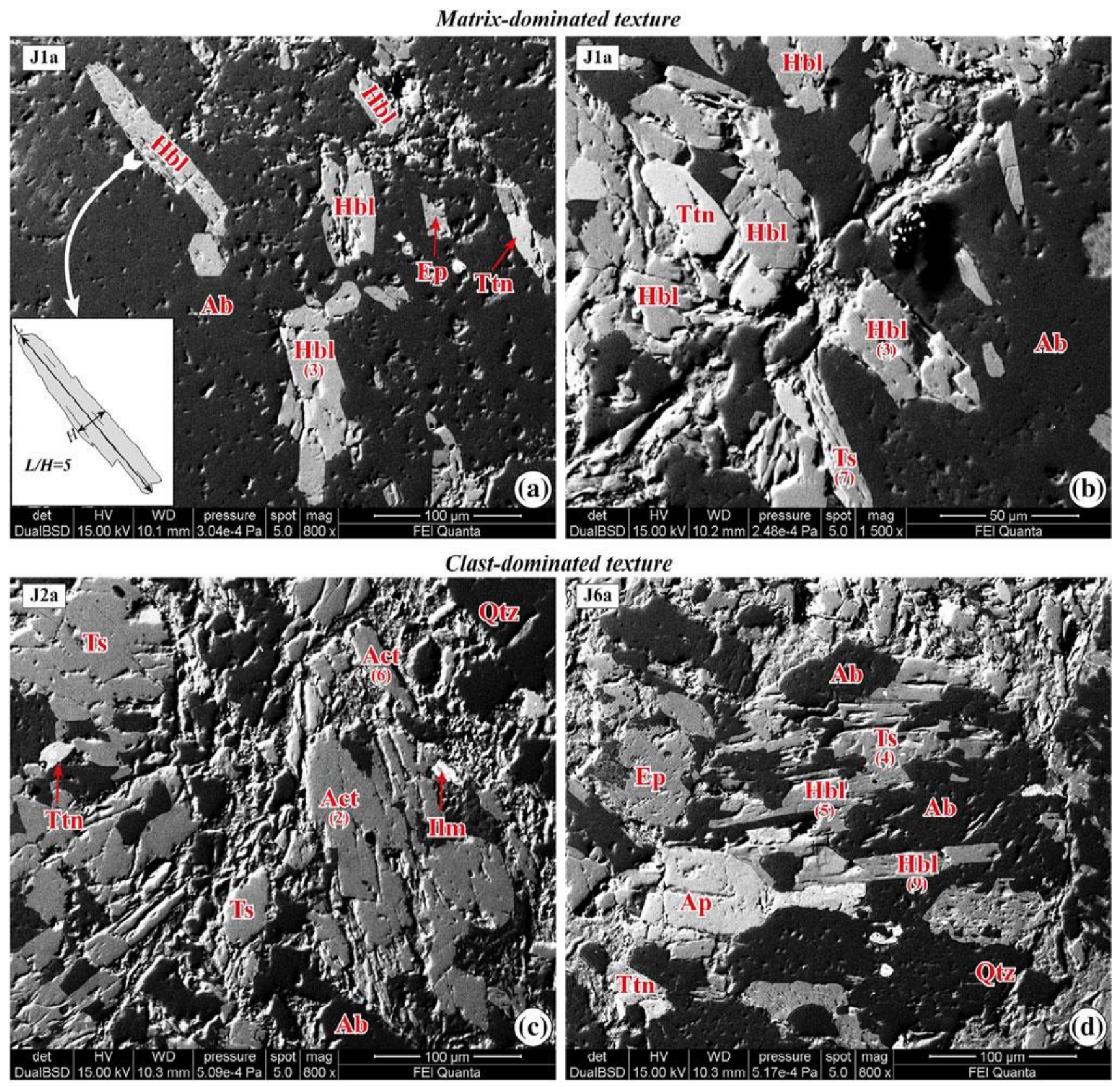

Fig. 9 SEM images of characteristics in matrix-dominated textures $(\mathbf{a}, \mathbf{b})$ and clasts dominated textures (c, d). Numbers represent the amphiboles aspect ratio estimated as shown in the insert in (a)

essential when assessing a heterogeneous quarry. The geological multidisciplinary approach allowed four main zones within the deposit to be distinguished, with properties which would be relevant for four different commercial sectors. Rock excavated from Sectors I, II, and IV have properties suitable for the production of railway ballast, road sub-base etc.

The study was undertaken to investigate the occurrence of asbestos in the ophiolitic rocks in the quarry as the presence of asbestos is strictly controlled by Italian legislation. The minero-petrographic analysis allowed a correlation to be made between rock textures and mineralization, which indicated that no asbestiform amphiboles would be encountered within the rocks being quarried. It is emphasized that a rigorous geological multidisciplinary approach (in terms of geological-structural fieldwork, minero-petrography, mineral chemistry and mineral morphology) is the key to discriminating where hazardous material is likely to occur.

The problems of interpreting the restrictive legislation regarding the presence of asbestos is discussed and attention is drawn to the difficulty of using the term 


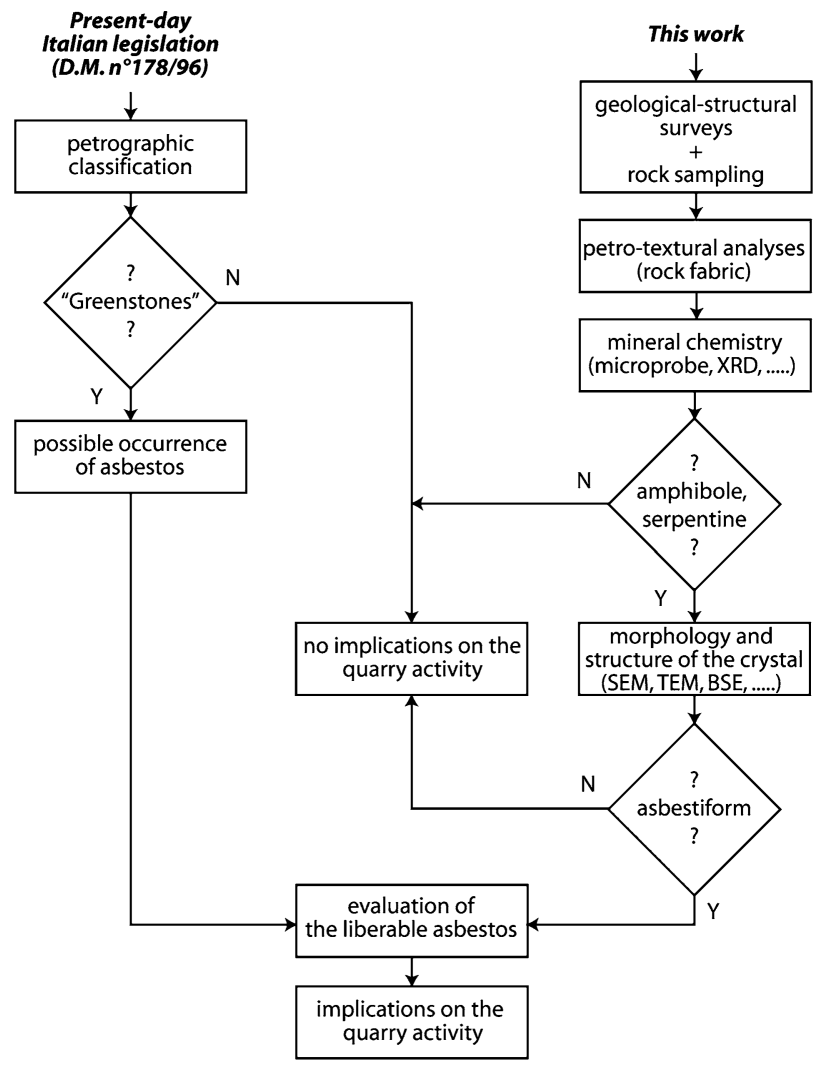

Fig. 10 Flow chart comparing rationale from Italian legislation (D.M. n.178, 14 May 1996) and the proposed methodology in order to evaluate the implications for quarrying activities with respect to the asbestos occurrence

"greenstones" which has various geological meanings in different countries. A reconsideration of the criteria adopted to classify materials for industrial use is recommended, particularly where countries have a close economic relationship, as in the European Community.

Acknowledgments The staff of the MINERALS ABBAU GMBH Company are acknowledged for their kind cooperation. Many thanks in particular to: G. Moretti and W. Strasser for their collaboration and scientific suggestions; G. Santoro for support during and after our stay in the quarry area. F. Rossetti is thanked for suggestions on a previous version.

\section{References}

Andreani M, Boullier AM, Gratier JP (2005) Development of schistosity by dissolution-crystallization in a Californian serpentinite gouge. J Struct Geol 27:2256-2267

Belardi G, Spaziani E, Passeri L (2008) La prova di automacinazione secondo il D.M. 14 maggio 1996: analisi degli effetti prodotti dalle principali variabili operative sulla curva granulometrica ottenuta a seguito del test. GEAM 2:5-10

Bucher K, Frey M (2002) Petrogenesis of metamorphic rocks. Springer, Berlin, p 341

Churg A, Wiggs B (1984) Fiber size and number in amphibole asbestos-induced mesothelioma. Am J Pathol 115:437-442
Compagnoni R, Groppo C (2006) Gli amianti in Val di Susa e le rocce che li contengono. Rend Soc Geol It 3:21-28

Dilek Y and Robinson PT (2003) Ophiolites in earth history. Geol Soc Lond Sp Pub 218

Doll R (1955) Mortality from lung cancer in asbestos workers. Br J Ind Med 12:81-86

Gibbons W (1998) The exploitation and environmental legacy of amphibole asbestos: a late 20th century overview. Environ Geochem Health 20:213-230

Gunter ME, Belluso E, Mottana A (2007) Amphiboles: environmental and health concerns. Rev Mineral Geochem 67:453-516

Harper M, Gyung Lee E, Doorn SS, Hammond O (2008) Differentiating non-asbestiform amphibole and amphibole asbestos by size characteristics. J Occup Environ Hyg 5:761-770

Hendrickx M (2009) Naturally occurring asbestos in eastern Australia: a review of geological occurrence, disturbance and mesothelioma risk. Environ Geol 57:909-926

Hirauchi KI, Yamaguchi H (2007) Unique deformation processes involving the recrystallization of chrysotile within serpentinite: implications for aseismic slip events within subduction zones. Terra Nova 19:454-461

Hubmann B, Suttner TJ, Messner F (2006) Geologic frame of Palaeozoic reefs in Austria with spezial emphasis on Devonian reef-architecture of the Graz Palaeozoic. Joannea Geol Paläont $8: 47-72$

Hughes JM, Weill H (1991) Asbestosis as a precursor of asbestos related lung cancer: results of a prospective mortality study. Br J Ind Med 48:229-233

IARC (International Agency for Research on Cancer) (1987) Monographs on the evaluation of carcinogenic risks to humans. Overall evaluations of carcinogenicity: an updating of IARC monographs, vol. 42, suppl 7. Springer-Verlag, New York, p 440

ISRM (1978) Suggested methods for the quantitative description of discontinuities in rock masses. Int $\mathbf{J}$ Rock MinSci Geomech Abstr 15:319-368

Italian Ministerial Decree No 178, 14 May (1996) Normative e metodologie tecniche per gli interventi di bonifica, ivi compresi quelli per rendere innocuo l'amianto, previsti dall'art. 5, comma 1, lettera f), della legge 27 marzo 1992, n. 257, recante: "Norme relative alla cessazione dell'impiego dell'amianto". Published in the Official Journal of the Italian Republic no. 251 of 25 October 1996, Ordinary Supplement

Karkanas P (1995) The slip-fiber chrysotile asbestos deposit in the Zidani area, northern Greece. Ore Geol Rev 10:19-29

Kazan-Allen L (2005) Asbestos and mesothelioma: worldwide trends. Lung Cancer 49(S1):S3-S8

Krainer K (1992) Fazies, Sedimentationsprozesse und Paläogeographieim Karbon der Ost- und Südalpen. Jb Geol B-A 135:99-193

Krainer K, Mogessie A (1991) Composition and significance of resedimented amphibolite breccias and conglomerates (Badstub Formation) in the Carboniferous of Nötsch (Eastern Alps, Carinthia, Austria). Jb Geol B A 134:65-81

Krainer K, Vachard D (2002) Late Serpukhovian (Namurian A) microfacies and carbonate microfossils from the carboniferous of Nötsch (Austria). Facies 46:1-26

Kretz R (1983) Symbols for rock-forming minerals. Am Mineral 68:277-279

Läufer AL, Hubich D, Loeschke J (2001) Variscan geodynamic evolution of the Carnic Alps (Austria/Italy). Int J Earth Sciences 90:855-870

Leake BE, Wooley AR, Arps CES, Birch WD, Gilbert MC, Grice JD, Hawthorne FC, Kato A, Kisch HJ, Krivovichev VG, Linthout K, Laird J, Mandarino JA, Maresch WV, Nickel EH, Rock NMS, Schumacher JC, Smith DC, Stephenson NCN, Ungaretti L, Whittaker EJW, Youzhi G (1997) Nomenclature of amphiboles: 
report of the subcommittee on amphiboles of the international mineralogical association, commission on new minerals and mineral names. Can Mineral 35:219-246

Leake BE, Wooley AR, Birch WD, Burke EAJ, Ferraris G, Grice JD, Hawthorne FC, Kisch HJ, Krivovichev VG, Schumacher JC, Stephenson NCN, Whittaker EJW (2004) Nomenclature of amphiboles: additions and revisions to the International Mineralogical Association's amphibole nomenclature. Am Mineral 89:883-887

Lee RJ, Strohmeier BR, Bunker KL, Van Orden DR (2008) Naturally occurring asbestos-a recurring public policy challenge. J Hazard Mater 153:1-21

Mossman BT, Bignon J, Corn M, Seaton A, Gee JBL (1990) Asbestos: scientific developments and implications for public policy. Science 247:294-301

Palmer MA, Bernhardt ES, Schlesinger WH, Eshleman NK, Foufoula-Georgiou E, Hendryx MS, Lemly AD, Likens GE, Loucks OL, Power ME, White PS, Wilcock PR (2010) Mountaintop mining consequences. Science 327:148-149

Pan XL, Day HW, Wang W, Beckett LA, Schenker MB (2005) Residential proximity to naturally occurring asbestos and mesothelioma risk in California. Am J Respir Crit Care Med 172:1019-1025

Räisänen M, Torppa A (2005) Quality assessment of a geologically heterogeneous rock quarry in Pirkanmaa county, southern Finland. Bull Eng Geol Environ 64:409-418

Rohl AN, Langer AM, Selikoff IJ (1977) Environmental asbestos pollution related to use of quarried serpentine rock. Science 196:1319-1322
Ross M, Nolan RP (2003) History of asbestos discovery and use and asbestos-related disease in context with the occurrence of asbestos within ophiolite complexes. Geol Soc Am Sp Paper 373:447-470

Spear FS (1993) Metamorphic phase equilibria and pressuretemperature-time paths. Mineralogical Society of America, Washington, p 799

Trommsdorff V, Evans BW (1974) Alpine metamorphism of peridotitic rocks. Schweiz Mineral Petrogr Mitt 54:333-352

Tucker ME (2001) Sedimentary petrology: an introduction to the origin of sedimentary rocks. Third edition, Wiley-Blackwell, p 262

Van Gosen BS (2007) The geology of asbestos in the United States and its practical applications. Environ Eng Geosci 13:55-68

Van Orden DR, Allison KA, Lee RJ (2008) Differentiating amphibole asbestos from non-asbestos in a complex mineral environment. Indoor Built Environ 17:58-68

Vignaroli G, Rossetti F, Belardi G, Billi A (2011) Linking rock fabric to fibrous mineralisation: a basic tool for the asbestos hazard. Nat Hazard Earth Sci Sys 11:1267-1280

Walton WH (1982) The nature, hazards and assessment of occupational exposure to airborne asbestos dust: a review. Ann Occup Hyg 25:117-119

World Health Organization (1986) Asbestos and other natural mineral fibres. Env Health Crit 53. Geneva

Yavuz F (2007) WinAmphcal: a Windows program for the IMA-04 amphibole classification. Geochem Geophys Geosys 8(1). doi:10.1029/2006GC001391 